\title{
Current Educational Policies of Political Parties in Turkey
}

\author{
Ismail Erol \\ Education Management, Namik Kemal University \\ Tekirdag, Turkey \\ E-mail: ismailerol59@hotmail.com \\ Munevver Cetin \\ Education Management, Marmara University \\ Istanbul, Turkey \\ E-mail: munevverolcum@gmail.com
}

\begin{abstract}
This research a section from the literature of the doctoral thesis titled "Examining the Views of the Legislative Power on Turkish Educational Administration" under the guidance of Prof. Dr. Munevver CETIN at the Institute of Educational Sciences, Marmara University.
\end{abstract}

\begin{abstract}
The education system is one of the most important stakeholders for its ever-changing and effective development and competitiveness. Education systems are important for raising qualified individuals and bringing them into society. In order for education systems to be regular and long-lasting, qualified education policies should be determined and used in educational management practices. In education policy in Turkey it is known to be important for both the state and government programs. Government policies are longlasting. Government policies change more frequently. One of the problems in educational policies: instability as a result of frequently changing governments. The space community the confidence of political parties and the government authority determines that the current education policies in the quest to create in Turkey, is important for the Turkish education system. In this study, current educational policies in surpassing the threshold into parliament in the general elections on June 24, 2018 Date of political parties in Turkey 6 of the program were examined. Considering the educational policies of the political parties in the parliament; it is seen that the education policies of all political parties are formed according to different ideological views. The education policies of AK Party, which marked the determination of the training programs of the last 15-20 years, are considered to be important in terms of theory and practice. It is thought that this research will contribute to studies on Turkish education system, management and policies.
\end{abstract}

Keywords: Education management, Education policies, Political parties, Legislative power

\section{Special Issue of Educational Sciences}

DOI: $10.7176 / J S T R / 6-06-07$

\section{Türkiye’deki Siyasi Partilerin Güncel Eğitim Politikaları}

\author{
Bu araştırmada Marmara Üniversitesi Eğitim Bilimleri Enstitüsünde Prof. Dr. Münevver ÇETİN danışmanlı̆̆ında \\ yürütülmekte olan "Yasama Erkinin Türk Ĕgitim Sistemi Yönetimine İlişkin Görüşlerinin İncelenmesi” isimli doktora \\ tezinin literatüründen bir bölüm sunulmuştur.
}

Özet

Sürekli değişen ve gelişen dünyada üzerinde ülkelerin kalkınması ve diğer ülkeler ile rekabet edebilmesi adına en önemli paydaşlardan birisi eğitim sistemleridir. Eğitim sistemleri, nitelikli bireylerin yetiştirilmesi ve topluma kazandırılması için önem arz etmektedir. Eğitim sistemlerinin düzenli ve uzun ömürlü olabilmesi için nitelikli eğitim politikalarının oluşturulması ve bu politikaların eğitim yönetimi uygulamalarında kullanılması gerekmektedir. Türkiye'de eğitim politikalarının oluşturulmasında hem devlet hem hükümet programlarının önemli olduğu bilinmektedir. Devlet politikaları daha uzun ömürlü olurken hükümetlerin politikaları ise daha sık değişmektedir. Eğitim politikalarındaki problemlerden birisi de sık değişen hükümetler neticesinde istikrar sıkıntılarıdır. Türkiye'de toplumun güvenoyunu alan ve hükümeti $84 \mid \mathrm{P}$ a g e www.iiste.org 
oluşturmak için yetki arayışındaki siyasi partilerin belirledikleri güncel eğitim politikaları Türk eğitim sisteminin yol haritasını belirlemek adına önemlidir. Bu araştırmada Türkiye'de 24 Haziran 2018 tarihi itibariyle yapılan son genel seçimlerde barajı aşarak meclise giren 6 siyasi partinin programlarında yer alan güncel eğitim politikaları incelenmiştir. Mecliste yer alan siyasi partilerin programlarındaki eğitime ilişkin politikalara bakıldığında; tüm siyasi partilerin eğitim politikalarının farklı ideolojik görüşe ve düşünceye göre şekillendiği görülmektedir. Türkiye'de özellikle son 15-20 yılın eğitim programlarının belirlenme sürecine damga vuran AK Parti'nin programlarındaki eğitim politikalarının teori ve uygulama açısından incelenmesi önem teşkil etmektedir. Bu araştırmanın Türk eğitim sistemi, yönetimi ve politikaları ile ilgili çalışmalara katkı sağlayacağı düşünülmektedir.

Anahtar Kelimeler: Eğitim yönetimi, Eğitim politikaları, Siyasi partiler, Yasama erki

\section{Giriş}

Günümüzde toplumların kalkınabilmesi ve inovasyon odaklı gelişmeleri takip edebilmesi adına en önemli dayanak "eğitim" olarak görülmektedir. Eğitim, toplumlarda her zaman kültür, ekonomi ve siyasetin kesişim noktasında bulunmuş ve devletlerin bu konularda yürüttükleri çalışmalarda önemli görevleri üstlenmiştir (Güllüpınar ve Bakış, 2015). Ayrıca eğitim, bu kesişim sayesinde toplumları oluşturan ve yenileyen bir süreci temsil etmektedir. Eğitim sistemlerinin toplum üzerinde hem kültürel, hem ekonomik, hem de siyasal işlevleri bulunmaktadır. İşte bu noktada Türkiye'nin kalabalık bir nüfusa sahip olduğu ve yaklaşık 18 milyon öğrencisinin varlığı düşünüldüğünde, devleti yönetmeye aday olan siyasi partilerin programlarında toplumu etkileyecek eğitim başlıklarının olması ve bu başlıklarda siyasi partilerin eğitim politikalarının vatandaşlara sunulması gayet doğaldır. Eğitim politikaları; eğitim sistemi ile ilgili yönetim, denetim, bütçe, planlama, istihdam, felsefe vb. tüm bu değerlere politika belirleyiciler veyahut iktidarlar tarafindan karar verilmesi sürecini ifade eder (Usta, 2015). Demokratik devletlerde siyasi partilerin parti programlarındaki eğitimle ilgili politikalar; toplumların şekillenmesi, nitelik kazanması, evrenselleşmesi ve günceli yakalayabilmesi adına önem arz etmektedir.

Siyasi partiler halkın oyunu alarak iktidarı kazanmak adına belli bir program etrafında toplanan kuruluşlardır (Kapani, 2006, s.176). Siyasi partiler, seçmenlerini çok iyi analiz etmeli, oylarını kullanırken hangi davranışları sergilediklerini ve hangi olaylardan etkilendiklerini bilmeleri gerekmektedir. Seçmenlerinin davranışlarını iyi analiz edemeyen siyasi partiler seçimlerde başarı elde edemezler (Şahin, 2011). Siyasi partiler demokratik yapıların vazgeçilmez üyeleridir. Siyasi partiler bulundukları toplumları yönetmek amacı ile bazı proje ve hedefleri seçmenlerine parti programlarında sunarak onlardan kabul almak isterler. Bu parti programları ülkenin tüm sorunlarını kapsayacak biçimde olmalıdır. Eğitimden sağlığa, sanayiden tarıma, ekonomiden sosyal problemlere, istihdamdan insan gücüne ve daha pek çok konunun siyasi partilerin çözmek istedikleri temel şemayı oluşturduğu görülmektedir (Berber, 2004). Tüm siyasi partiler eğitim alanında belirledikleri problemleri, ortaya koymak istedikleri değişiklikleri ve düzenlemeleri parti programlarında açıklarlar (Bulut ve Güven, 2010). Türkiye'de devlet politikalarının uygulanması yürütme organı olan hükümetler tarafindan gerçekleştirilmektedir. Pek çok ulusal ve uluslararası politika belgeleri ve yasal dayanaklar eğitim ile ilgili hükümetlere önemli sorumluluklar yüklemektedir (Aksoy vd., 2011). Siyasi partilerin bu sorumluluklara sahip olması için parti programları ile halkı etkilemesi ve onların yararına olacak vaatleri seçmenlerine aktarması gerekmektedir. Bu neticede eğitim programları, kendilerine oy verecek vatandaşlara ulaşma açısından önem teşkil etmektedir.

Türkiye'de eğitim politikalarına yön veren bazı örgütler vardır. Bu örgütlerin başında Milli Eğitim Bakanlığı gelmektedir. Yine eğitim politikalarının belirlenmesinde Milli Eğitim Şuraları da tavsiye niteliği taşımaktadır. Aynı zamanda eğitim politikalarına yol haritası olan kurum, Kalkınma Bakanlığı' dır. İşte eğitim politikalarına yön veren bu kurum ve kuruluşları şekillendiren yetki mercii siyasi partiler tarafından kurulan hükümetlerdir. Hükümetlerin de bağlı bulundukları siyasi partilerin eğitim programları ve devlet politikalarını harmanlayarak icraatlarını oluşturdukları görülmektedir. Hükümetlerin oluşturdukları politikaların en önemli desteğinin hükümetleri oluşturan siyasi partilerin parti programları olduğu düşünülürse, Türkiye'nin genel eğitim politikalarını anlamak adına siyasi partilerin programlarının içeriğinin incelenmesi önem teşkil etmektedir (Usta, 2015).

Siyasi partiler, seçimlerden önce halka sundukları seçim bildirgeleri ile pek çok vaatte bulunmuş olsalar bile bu vaatleri hükümeti kurunca yerine getireceklerine dair bir garanti yoktur. Hatta bu sunulan vaatlerin birçoğunu uygulama ve gerçekleştirme konusunda yetersiz kalmaktadırlar (Atmış ve Günşen, 2016). Bu sebeple mevcut iktidardaki siyasi partilerin seçimlerden önceki parti programlarında bulunan eğitim politikaları önerilerinin teori ve uygulama açısından incelenmesi önemlidir.

Türkiye'deki siyasi partilerin eğitim politikaları, eğitim programları ve seçim beyannamelerindeki eğitim

$85 \mid \mathrm{P}$ a g e

www.iiste.org 
söylemleriyle ilgili literatürde sınırlı sayıda çalışma bulunmaktadır. Özdem (2015), Türkiye'de eğitim politikaları ile ilgili yapılmış olan lisansüstü tezleri incelediği çalışmasında YÖK'e kayıtlı 126 tezi incelemiştir. Araştırmada eğitim politikaları ile ilgili gerçekleştirilen tez çalışmalarında en fazla $\mathrm{AB}$ eğitim politikalarının, ilköğretim eğitim politikalarının, Atatürk dönemindeki eğitim politikalarının çalışıldığını; kalkınma-eğitim, planlama-eğitim ve ideoloji-eğitim politikaları ilişkisinin ve karşılaştırmalı eğitim politikalarının da en az çalışılmış konular olduğunu dile getirmiştir. Mevcut çalışmalardan bir diğeri de Akça vd. (2018)'nin gerçekleştirdikleri siyasi partilerin beyannamelerinde bulunan eğitim politikalarını inceleyen çalışmadır. Bu çalışmada, siyasi partilerin iktidara geldiklerinde izleyecekleri eğitim politikaları, eğitime yönelik neler yapacakları siyasi partilerin internet sayfalarından elde edilen veriler ile incelenmiştir. Araştırmada bütün siyasi partilerin programlarında eğitim konusuna yer verdiğine, fakat genel olarak tüm siyasi partilerin aynı politikaları dile getirdiklerine değinilmiştir. Parti programları incelendiğinde eğitimdeki problemlere çözüm üretecek önerilere ihtiyaç olduğunu dile getiren çalışmada, eğitimin Türk milletinin ortak geleceği olduğuna, toplumsal sorunların çözümünün eğitim ile sağlanacağına, sosyal ve siyasal hayatta modernleşme sağlanabilmesi adına eğitimin yetiştireceği hür fikirli, hür vicdanlı bireylere ihtiyaç duyulduğuna dikkat çekilmiştir. Yine farklı bir çalışmada Altınışık ve Songür (2016), 2015 seçimleri neticesinde barajı aşan partilerin eğitimin niteliği ile alakalı politikalarını çözümlemeye çalışmıştır. Bu çalışma neticesinde, partilerin bildirgelerinde eğitim sistemine farklı kapsam ve başlıklarda yer verdiklerini aynı zamanda eğitim anlayışlarına partilerin ideolojik görüşlerinin yansıdığını dile getirilmiştir. Korkmaz (2018) ise çalışmasında; siyasi partilerin 2018 Cumhurbaşkanlığı ve Genel Seçimlerdeki bildirgelerindeki eğitime yönelik görüşleri incelemiştir. Çalışma neticesinde Korkmaz'da seçim bildirgelerini incelediği beş siyasi partinin de eğitime yönelik farklı bakış açıları olduğu sonucuna ulaşmıştır. Berber (2001) ise tüm bu farklılıkların temelinde farklı ideolojik görüşlerin olduğunu dile getirmektedir. Bulut ve Güven (2013)'de siyasi partilerin programlarındaki ilköğretimi incelediği çalışmalarında, siyasi partilerin ilköğretim basamağında hedefledikleri uygulamaların birbirinden farklı olduğuna, bunlardan bazılarının AK Parti'nin okullardaki fiziki yapılar ve donanımlar; MHP'nin çevre eğitimleri konularındaki ifadeleri olduğu ortaya çıkmaktadır. Araştırma konusu ile ilgili bir başka çalışmada ise Su (2017), AK Parti Dönemi 59. ve 60. hükümetlerdeki eğitim politikalarını incelemiştir. Araştırma sonuçlarında AK Parti’nin hükümet olarak eğitim politikalarını gerçekleştirdiği görülmektedir.

Büyükboyacı (2015), gerçekleştirilen eğitim planlamalarının temel hedefinin eğitim öğretim faaliyetlerinin belli bir çerçevede verimli ve düzenli yürümesi olduğuna; bu yürütme faaliyetlerini uygulayabilecek kurumların demokratik sistemler içerisinde ülkenin bütününde söz sahibi olan siyasi partiler olduğuna; araştırma sonuçlarında ve basındaki haberler neticesinde siyasi partilerin belirlediği eğitim politikalarının ülkenin kalkınması ve gelişmesinde önemli olduğuna değinmiştir. Bu çalışma siyasi partilerin parti programlarındaki eğitim politikalarının ortaya çıkarılması, eğitime yönelik görüşlerinin tespit edilmesi, iktidara geldiklerinde nasıl bir eğitim sistemi kurgulayacaklarının öngörülmesi ve parti programlarında ne sıklıkla eğitim politikalarına yer verdiklerinin tespit edilmesi açısından önemlidir. $\mathrm{Bu}$ neticede siyasi partilerin eğitim sistemine yönelik sunacakları politikaların hangi sorunlara yönelik çözüm önerileri ortaya çıkardığının görülmesi ve mevcut iktidarın bu çözüm önerilerinden hangilerini gerçekleştirdiğini tespit etmek için önem teşkil etmektedir.

\section{Amac}

Parti programları, devlet ile millet arasında bağ oluşturan siyasi partilerin iktidar olduklarında yürütmek istedikleri politikaları içeren bir yol haritasıdır. Türkiye'de parti programlarında en önemli konu başlıklarından birisinin "eğitim politikaları” olması doğaldır. Bu araştırmanın temel amacı; Türk eğitim politikalarının belirlenmesinde önemli görevleri bulunan ve 24 Haziran 2018 genel seçimlerine girerek mecliste sandalyesi bulunan partilerin programlarında yer alan eğitim politikalarının incelenmesidir. Bu araştırma kapsamında öncelikle literatür araştırması yapılarak siyasi partilerin programlarına ulaşılmış, programların incelemesi yapılmış, sınırlıklar belirlenmiş ve yorumlamalar yapıllmıştır. Araştırmada parti programlarının incelenmesi "Eğitim", "Eğitim Politikaları" ve "Eğitim Sistemi” ile sınırlandırılmıştır. Araştırmada aşağıdaki alt amaçlara cevap aranmıştır:

1. Türk eğitim sisteminde siyasi partilerin rolü nedir?

2. Siyasi partilerin parti programlarında eğitim politikaları ne ölçüde yer kaplamaktadır?

3. Siyasi partiler oluşturdukları eğitim politikaları bağlamında birbirinden ne ölçüde ayrılmaktadır?

4. Eğitim politikaları neticesinde siyasi partilerin teori ve uygulamaları ne ölçüde bağdaşmaktadır?

5. Mevcut iktidardaki siyasi partinin eğitim politikalarını uygulama düzeyi ne ölçüdedir? 


\section{Yöntem}

$\mathrm{Bu}$ araştırmada nitel araştırma yöntemlerinden olan "Doküman analizi” yöntemi kullanılmıştır. Doküman analizleri araştırmaların hedeflerine yönelik olarak verilere ulaşmak için dokümanların incelenmesi yoluyla gerçekleşmektedir (Çepni, 2010). Genel olarak konu ile ilgili derinlemesine gözlem ve görüşme yapma imkânının olmadığı hallerde başvurulan bir yöntem olarak bilinen doküman incelemeleri, araştırılması amaçlanan olgu ya da olaylar ile ilgili yazılı bilgi kaynaklarının detaylı bir şekilde analiz edilmesidir (Şimşek vd., 2009). Araştırma neticesinde 24 Haziran 2018 tarihinde gerçekleştirilen 27. Dönem Milletvekili Genel Seçimleri sonucunda Türkiye Büyük Millet Meclisi'nde vekili bulunan Adalet ve Kalkınma Partisi, Cumhuriyet Halk Partisi, İyi Parti, Milliyetçi Hareket Partisi, Halkların Demokratik Partisi ve Saadet Partisi'nin parti programlarının eğitim ile alakalı kısımları ve Adalet ve Kalkınma Partisi'nin vaatleri ve icraatlarını kıyaslamak adına 2018 seçim bildirgesinin eğitimi ilgilendiren bölümleri incelenmiştir. Bu araştırmanın belgeleri olarak ele alınan yazılı unsurlar; siyasi partilerin resmi internet adreslerinde yayımladıkları parti programlarıdır. Araştırmada verileri toplayabilmek adına siyasi partilerin güncel internet adreslerine gidilerek, parti programlarında "eğitim", "eğitim politikaları", "eğitim sistemi" kelimeleri ile aramalar gerçekleştirilmiştir.

\section{Bulgular}

Araştırmanın bu bölümünde, Türkiye'deki siyasi partilerin programları ve uygulama rehberlerinde yapılan analizler sonucunda elde edilen bulgulara yer verilmiştir.

\subsection{Siyasi Partilerin Ĕ̈itim Politikalart}

Türkiye'de 24 Haziran 2018 tarihinde gerçekleştirilen genel seçimler neticesinde mecliste yer alan (AK Parti) Adalet ve Kalkınma Partisi, (CHP) Cumhuriyet Halk Partisi, (İYİ Parti) İyi Parti, (MHP) Milliyetçi Hareket Partisi, (HDP) Halkların Demokratik Partisi ve Saadet Partisi'nin parti programları incelenmiş; ekonomik, sosyal ve politik olarak eğitim politikalarına bakış açıları analiz edilmiştir. Siyasi partilerin eğitim politikaları tablo 1'de gösterildiği üzere; Adalet ve Kalkınma Partisi'nin eğitim politikaları, Milliyetçi Hareket Partisi'nin eğitim politikaları, Cumhuriyet Halk Partisi'nin eğitim politikaları, İyi Parti'nin eğitim politikaları, Saadet Partisi'nin eğitim politikaları, Halkların Demokratik Partisi'nin eğitim politikaları ve Siyasi partilerin eğitim politikalarının teori ve uygulama açısından incelenmesi başlıkları altında sunulmuştur.

Tablo 1. Siyasi partilerin eğitim politikalarının incelenmesi başlıkları

SIYASI PARTILERIN EĞITIM POLITIKALARININ INCELENMESi

\begin{tabular}{c} 
Adalet ve Kalkınma Partisinin Eğitim Politikaları \\
Milliyetçi Hareket Partisinin Eğitim Politikaları \\
Cumhuriyet Halk Partisinin Eğitim Politikaları \\
IYİ Partinin Eğitim Politikaları \\
Saadet Partisinin Eğitim Politikaları \\
Halkların Demokratik Partisinin Eğitim Politikaları \\
Siyasi Partilerin Eğitim Politikalarının Teori ve Uygulama Açısından İncelenmesi \\
\hline
\end{tabular}

\subsection{Adalet ve Kalkınma Partisinin Ĕgitim Politikaları}

Adalet ve Kalkınma Partisi’nin (2018) parti programı incelendiğinde eğitimin her alandaki kalkınmanın en önemli unsuru sayıldığı görülmektedir. Bu programda, "Sosyal Politika Anlayışının” "Eğitim” teması başlı̆̆ı altında şu hususlara değinilmiştir:

- Beşeri sermayesini nitelikli kullanmayan toplumların, rekabet şansını kaybetmeye mahkûm olduğu dile getirilmiştir. Bu sebeple AK Parti, kamu kaynaklarını tahsis ederken birinci öncelik unsurunun eğitim ve eğitime yapılacak yatırımlar olması gerektiğine inanmaktadır. AK Parti’ye göre eğitim sisteminde oluşabilecek zaaflar, hiçbir alanda gerçekleştirilecek üstünlük çabaları ile ortadan kaldırılamaz. Bununla beraber eğitim sisteminde gerçekleştirilecek üstün başarıların diğer bütün alanlardaki toplam kaliteyi

87 | P a g e

www.iiste.org 
yükselteceğine değinilmiştir. Eğitim sistemine bu bilinç ile yaklaşan AK Parti, bu alanda giderek çoğalan zaafları ortadan kaldırmayı öncelik arz eden hedefler arasına almaktadır.

- AK Parti’ye göre Türkiye eğitim alanı ile ilgili ciddi bir karmaşa içerisindedir. Eğitimin kalitesi, olması gereken durumun çok altında bulunmaktadır. Eğitimde olması gereken firsat eşitliği her gün git gide ortadan kalkmaktadır. Türkiye'de eğitim sistemi ideolojik çıkar ve kavgalar arenası haline getirilmiştir. Eğitim çalışmaları; araştırmalar ve istihdam planlamaları olmadan gerçekleştirilmektedir. Yükseköğretim basamağındaki kurumlar dâhil olmak üzere, eğitim hizmeti veren kurumların çoğundan nitelikli eğitim anlayışının dışında, diplomalı işsiz bireylerin mezun olduğu dile getirilmiştir.

Bu hususlardan dolayı AK Parti, eğitim alanında köklü bir reform hareketine girişeceğini parti programında dile getirmektedir. Bu reform hareketlerinin özeti şu şsekildedir (AK Parti Eğitim Programı, 2018):

- Türkiye'de oldukça yetersiz seviyedeki okul öncesi eğitim sistemine verilen önem, özel sektör ve kamu vasitası ile ülkenin genelinde arttrrılacaktır.

- Temel eğitimde uygulanan müfredatın çağın gereksinimlerine, ihtiyaçlarına ve öğrencilerin kazanacakları donanımlara göre tekrardan meydana getirilmesi planlanmaktadır. Temel eğitim hizmeti uygulamalarının pilot çalışmalar ile merkezi idaredeki taşra birimleri ve yerel yönetim birimlerine devredilmesi gündemdedir. MEB'in ise düzenleyici, denetleyici ve standartları oluşturan bir konumda bulunması sağlanacaktır. Bölge olarak yoksul kesimlerde eğitim çalışmaları devlet tarafindan gerçekleştirilerek bu bölgeler özel programlar ve projeler ile desteklenecektir.

- Halen yürürlükte olan üniversite giriş sistemindeki uygulamaların, öğrenci motivasyonunu azaltan ve hakkaniyete aykırı sonuçlar açığa çıkardığı dile getirilmiştir. Bu uygulamalardaki problemlerin öncelikli olarak gündeme alınması, üniversite giriş sınavları uygulamalarında bütün lise ve dengi okullardan mezun olanlara firsat eşitliğinin sağlanması planlanmaktadır.

- Kamu vasıtası ile temel eğitimin ücretsiz gerçekleştirilmesi dile getirilmiştir. Kamu okullarının eğitim kalitesinin yükseltilmesi, teknolojik imkânlarının arttırılması gündemdedir. Özgür düşünen ve analiz yapma alışkanlığını kazandıran; katılımcı, bağımsız kararlar verebilen ve üretim yeteneğini geliştiren; çoğulcu değerler sunabilen; iyi birer vatandaş olma bilincini arttıran; teknolojiyi ve çağdaş gelişmeyi öğreten bir eğitim sistemine adım atılacağına dikkat çekilmiştir. Bu dönüşüm sürecinde gelişmiş ve demokratik ülkelerdeki eğitim tecrübelerinden de istifade edilip, öğretmen yetiştiren okulların bu dönüşümler ışığında tekrardan yapılanması ve hali hazırdaki öğretmenlerin ise yeni sistemle beraber hizmet içi eğitimlere alınması planlanmaktadır.

- Temel eğitim basamağında 5. sınıf itibari ile "seçmeli dersler" programlara konularak öğrencilerin yetenek ve ilgilerine göre mesleki ve genel eğitim kurumlarına yönlendirilmelerinin gerçekleştirilmesi AK Parti'nin gündemindedir.

- Özel sektörün eğitime yatırım yapmasını sağlamak adına düzenlemelerin gerçekleştirilmesi, özel kurumların çoğaltılması ve mevcut okullarda \%100 kapasiteyle çalışılmasını temin edecek düzenlemelerin planlandığı görülmektedir. Başarı durumları ile maddi imkânı olmayan çocukların da özel okullarda okuyabilmesi adına devlet tarafından hizmet alımı yapılacağına, talepler oluşturup özel sektörün de eğitim alanındaki yatırımlara kaynak ayırmasının temininin sağlanacağına dikkat çekilmiştir.

- Mesleki ve teknik okullara gerekli önem gösterilerek bu okulların üniversite öncesinde diploma ve eğitim veren okullar değil, meslek kazandırmaya yönelik okullar arasında olması sağlanacaktır. İş adamlarının kurduğu STK'lar, Ticaret ve Sanayi Odaları ile beraber iş dünyasındaki ihtiyaçların belirlenip günün ihtiyaçlarını karşılayacak, dinamik mesleki eğitim programlarının oluşturulacağına değinilmiştir. Uzun süreli olan okulların programlarını takip edemeyecekler için kısa süreli meslek edindirme eğitimi kuruluşlarının kurulması planlanmaktadır. Kalkınma koşullarında öncelikli olan bölgelere mesleki eğitim alanında özel destek sağlayan programların uygulanması beklenmektedir.

- Öğrencilerin birikimleri ve yeteneklerine göre eğitim alacaklarına; bu neticede maddi imkânı olmayan öğrencilerin de kaliteli eğitim almasının sağlanacağına değinilmiştir. 
- Kamu üniversitelerinde okuyan öğrencilerin okul masrafları karşılanarak hayatlarını belli bir standarda göre devam ettirecekleri kredi sistemine geçilip, yoksul durumdaki öğrencilere yapılması planlanan yardımların ilke ve esaslarının belirleneceğine dikkat çekilmiştir.

- Ülkedeki mevcut ara eleman ihtiyaçlarını karşılama adına açılan meslek yüksek okullarını programlar dâhilinde yeni düzenlemelere tabi tutarak, bu okulların nitelikli bir şekilde ara eleman mezunu vermeleri sağlanacaktır.

- Yükseköğretim kurumlarına iş adamları, odalar ve yerel yönetimler ile birlikte ortak projeler yapmaları ve şirket oluşturabilmeleri adına firsatlar verilerek özel sektörün ve yerel yönetimlerin üniversiteler ile ilişkilerinin geliştirilmesini sağlayacak düzenlemelerin gerçekleştirilmesi AK Parti’nin gündemindedir.

- Merkezi yönetim sistemi devlet olarak ihtiyaç duyulan alan ve üniversitelerde gerçekleştirilecek olan teknoloji geliştirme ve araştırma programlarını destekleyip, üniversitelere bu hususlarda fon bulmasının sağlanması, bu neticede üniversitelerin sanayi kuruluşları ile işbirliği içinde olmaları, pratik faydaları ön planda tutan kurumlar olmaları sağlanarak, hayattan ve toplumdan uzak bir görüntü sergilememelerine değinilmiştir.

- Yükseköğretim sisteminin Türkiye'de niceliksel açıdan ciddi bir gelişim gösterdiği, fakat niteliksel açıdan aynı başarıyı yakalayamadığı aktarılmıştır. Yükseköğretim sisteminde köklü bir değişime ihtiyaç duyulduğuna değinilmiştir. Yükseköğretim Kurumunun üniversiteler arasında koordinasyonu sağlayan standartları oluşturan bir yapıya kavuşturularak; üniversitelerin akademik ve idari özerkliğe sahip, öğrenciler ve öğretim elemanları üzerinde dayatma, baskı ve antidemokratik uygulamaların olmadığ bilimsel açıdan bilgi üretiminin yapıldığı, öğretim ve araştırma faaliyetlerinin ön planda olduğu kurumlara dönüştürülmesi düşünülmektedir.

- Eğitim kurumlarının mimari özelliklerinin eğitsel ve fiziksel donanımlar açısından geliştirileceği; okullarda sınıfları esas almak yerine dersleri esas alan fiziki yapıların oluşturulacağı; okul inşasında tek tipliliğin terk edilip esnek bir yapılanma modeline geçileceği ifade edilmiştir.

- Rehberlik sisteminin ve okul-aile birliklerinin, sosyal bilimcilerin ortaya koyacağı projeler ile güçlendirilmesi ve desteklenmesine firsat sunulacağına değinilmiştir.

- Dünya üzerindeki bireylerle, toplumlarla ve milletlerarası iletişimin sağlanması adına yabancı dil öğrenmenin önemli olduğuna dikkat çekilmiştir. Bu sebeple yabancı dil eğitim sistemlerinin modern araçlar ve imkânlarla kolaylaştırılıp, kaliteli hale getirileceğine değinilmiştir. AK Parti'nin vatandaşları dil eğitimlerine teşvik ettiği, Türkçe'nin ise bilimsel bir dil olarak kullanımına destek olunup, özendirileceği dile getirmektedir.

- Yurtdışında yaşamakta olan vatandaşlar ve çocukları adına nitelikli eğitim olanaklarının sağlanması gündemdedir.

- İlke olarak laiklik gereksinimi olarak vatandaşların kendi dinlerini öğrenmesi adına tüm imkânların sağlanacağına, ilköğretim ve ortaöğretimde din kültürü ve ahlak bilgisi dersinden farklı olarak veli gönüllüğüne göre seçmeli olarak din derslerinin sunulacağına değinilmiştir.

- Gelişen teknolojik imkânların vatandaşlara internet üzerinden öğrenim alma imkânı verdiği aktarılmıştır. Üniversitelerde gerçekleştirilecek bu tip uygulamaların teşvik edilerek öğrencilerin internet üzerinden yapılacak öğretim sistemlerinden yararlanmalarının sağlanacağına dikkat çekilmiştir.

- Vakıf üniversitelerinin kurulmasının desteklenerek bu üniversitelerin bütçeden aldığı maddi desteklerin usul ve esaslarının tekrardan düzenleneceğine dikkat çekilmiştir.

Özel gereksinimli öğrencilerin eğitimlerine önem verilerek bu doğrultuda faaliyet gösteren vakıf, dernek ve sosyal yardım kuruluşlarının bünyesinde gerçekleşen faaliyetlerin özel bir biçimde destek göreceği dile getirilmiştir (AK Parti Programı, 2018).

\subsection{Milliyetçi Hareket Partisinin Ĕğitim Politikaları}

MHP’nin (2009, s.30) “Geleceğe Doğru” adını verdiği parti programında “Temel Hak ve Özgürlüklerin Teminat Altına Alınması” teması altında “Ĕgitim ve Öğretim” hakkında şu hususlara değinilmiştir:

Partimiz herkesin eğitim ve öğrenim hakkına sahip olduğuna ve bu hakkın her ne suretle

89 | P a g e

www.iiste.org 
olursa olsun engellenemeyecĕ̆ine, ĕgitim ve ögretimin devletin gözetim ve denetimi altında yapılması gerektiğine inanmaktadır. Eğitimin her kademesinde eğitim dilinin Türkçe olması, Türkçe'den başka hiçbir dilin eğitim ve ögretim kurumlarında Türk vatandaşlarına ana dilleri olarak okutulmaması ve ögretilmemesi esastır (MHP Parti Programı, s.30).

Yine MHP parti programına göre (2009); "Sosyal hedefler ve Politikalar" temasında "Eğitim ve İnsan Kaynaklarının Geliştirilmesi” " hakkında özetle şunlara değinilmektedir (Geleceğe Doğru, 2009, s.98):

4.3.1. Erdemli ve Demokrat Nesiller: Türk milletine mensup olmanın şuur ve gururuna sahip, kültürel ve manevi değerlerimizi özümseyen, algılama, problem çözme ve düşünme yetenekleri gelişmiş, yeniliklere açık, toplumsal duyarlılı̆̆ı ve sorumluluk duygusu yüksek seviyede, teknoloji ve bilim üretimine yatkın, demokratik, girişimci, inançlı ve kültürlü bireyleri yetiştirmenin MHP'nin eğitim politikalarının temel hedefi olduğuna dikkat çekilmiştir. Eğitim ve öğretim sisteminde fursat ve imkân eşitliğinin sağlanıp, toplumdaki bütün bireylerin ilgileri, eğilimleri ve yetenekleri ölçüsünde eğitilmelerine öncelik verileceğinden bahsedilmektedir.

4.3.2. Eğitimin ve Öğretimin Dili “Türkçe”: Eğitim sisteminin tüm basamaklarında eğitimin dilinin Türkçe olacağına değinilmiştir. Türkçe'den başka hiçbir dilin Türkiye'de eğitim kurumları içerisinde Türk vatandaşlarına ana dilleri şeklinde öğretilemeyeceğine ve okutulamayacağına dikkat çekilmiştir. Türk dilinin güzel ve doğru kullanımına ve öğretimine gerekli önemin gösterilerek aynı zamanda öğrencilere en az bir yabancı dil öğretilmesinin sağlanacağına değinilmiştir.

4.3.3. Modern Eğitim Sistemi: Eğitimin, bilgi toplumunda ihtiyaç duyulan beceri ve bilgilerle donanmış, uluslararası alanda rekabet edebilme yeteneğine sahip olan, teknolojik alanda kültürü gelişen nitelikli insan gücünün geliştirilmesini temin edecek biçimde tekrardan düzenleneceğine; bu neticede eğitim alanları, insan gücü olanakları ve eğitim teknolojilerinin nicelik ve nitelik açısından bilgi toplumunda ihtiyaç duyulan standarda getirileceğine; eğitim sisteminin her basamağında müfredatın çağın gereksinimlerine ve milli yapıya uygun bir biçimde uygulanması ve planlanmasın esas olacağına dikkat çekilmiştir.

4.3.4. Eğitim Süresinin Çoğaltılması: Temel eğitim basamağında okul öncesi eğitim basamağının yaygınlaştırılarak temel zorunlu eğitim süresinin arttırılması, gerekli olan fiziki alt yapının ve nitelikli insan gücü kapasitesinin oluşturularak ortaöğretim basamağının da zorunlu eğitimin içerisine alınması, eğitim sisteminin her basamağında etkin yönlendirmeler yapılarak öğrencilerin yeteneklerine uygun bölümlere gönderilmesi hedeflenmektedir.

4.3.5. Mesleki ve Teknik Eğitim: Yaygın ve örgün meslekî-teknik eğitime ve beceri kazandıran eğitimlere ağırlık verilerek, eğitim programlarının içeriğinin mesleki standartlara göre tekrardan düzenlenmesi, istihdamı arttıran mesleki eğitim sistemlerinin ortaöğretim içerisindeki payının arttırılması, Teknik ve mesleki ortaöğretim kurumlarıyla meslek yüksek okullarının program bütünlüğünün gerçekleştirilmesi ve iş yaşamıyla meslekî ve teknik eğitim arasındaki bağın ve etkileşimin arttırılacağına dikkat çekilmiştir.

4.3.6. Yükseköğretim Sistemi: Üniversitelerin Türkiye'nin gereksinim duyduğu nitelikli insan gücünü sağlayan, toplumsal olaylara öncülük eden, araştırmalar gerçekleştirerek teknoloji ve bilim üreten, bilimsel yöntemler ile problemlere çözüm yolları geliştiren ve diğer dünya üniversiteleri ile yarışır hale gelen eğitim kurumları arasında olmasının sağlanacağına değinilmiştir. Yükseköğretimin yapısının daha üretken ve demokratik bir yapıya kavuşturularak; öğrenciler, kurumlar ve akademik kadro arasındaki gerekli olan uyumun ve işbirliğinin sağlanacağına değinilmiştir. Ortaöğretim sisteminin program türlerini merkeze alan, dikey ve yatay geçişe olanak tanıyan, modern yönlendirme ve rehberlik hizmetleriyle üniversite basamağına etkin bir geçişi kolaylaştıran bir yapıya dönüştürüleceği ifade edilmiştir.

4.3.7. Yaşam Boyu Öğrenme: Yaşam boyu öğrenme ile e-öğretim modeli de dahil olacak şekilde tüm yaygın eğitim fırsatlarının geliştirilerek, gençlere meslek edindirme ve beceri kazandırma çalışmalarının arttırılacağına vurgu yapılmıştır.

4.3.8. Ĕgitici İnsan Kaynaklart: Çağın gerektirdiği bilgiler ile donanmış öğretim üyesi ve öğretmenlerin yetiştirip bu mesleklerin çalışma koşulları ile sosyal özlük haklarının daha cazip konuma yükseltilmesinin sağlanmasına gayret edileceğine değinilmiştir.

4.3.9. Gazi ve Şehit Çocukları Eğitimi: Gazi ve şehit çocuklarının eğitim harcamaları adına devlet bütçesinden pay ayrılması ve üniversitelere girişlerde kontenjan ayrılmasının sağlanacağına değinilmiştir.

4.3.10. Yurt Dışında Yaşayan Türk Çocuklarının Eğitim Durumu: Yabancı ülkelerde yaşamlarını sürdüren

$90 \mid \mathrm{P}$ a g e

WWw.iiste.org 
Türk evlatlarının kültürel benliklerini koruma ve geliştirme adına gerçekleştirilen eğitim fırsatlarının çoğaltılacağına vurgu yapılmaktadır (MHP Parti Programı, 2009).

\subsection{Cumhuriyet Halk Partisinin Eğitim Politikalart}

CHP’nin “Çăgdaş Türkiye İçin Değişim” adını verdiği parti programı kitapçı̆̆ında 6. bölümde "Sosyal Refah Devleti” içerisinde eğitim politikalarına geniş bir yer ayrılmıştır. Cumhuriyet Halk Partisi'nin eğitim politikaları "Eğitim Programı" içerisinde özetle şöyle ifade edilmektedir:

4.4.1. Ĕğitim aydınlı̆̆ın yoludur: En temel insani haklardan birisinin eğitim olduğu dile getirilmiştir. Ĕgitim hakkını, olanaklarını ve özgürlüklerini gençlerine ve çocuklarına yeterince ulaştıramayan ulusların çağın gereksinimlerine ayak uydurabilmelerinin olanaksız olduğuna değinilmiştir. CHP'nin eğitim sisteminin temel amacının Atatürk'ün de ifade ettiği gibi; fikri hür olan, vicdanı hür olan ve irfanı hür olan bireyler yetiştirmek üzerine kurulu olduğu vurgulanmıştır. Türk milli eğitim sistemindeki temel ilkelerin, Eğitim Yasası içerisinde olduğu şekliyle kesintisiz, eksiksiz ve bütünlük arz edecek biçimde uygulanmasının Parti'nin temel gayesi olduğu aktarılmıştır. Eğitim sistemini, toplumun ve devletin tüm bireylerinin ortak sorumluluğunda gören Cumhuriyet Halk Partisi, öğrenim hayatını ve öğretim sürecini siyasetten arındırıp, devletin bir politikası haline dönüştürme amacındadır.

4.4.2. Insanı Merkeze Alan Çăğdaş Eğitim Devrimi: CHP tarafından Türkiye’yi tüm yönleri ile bağımsız, özgür, modern, gelişmiş ve lider bir ülke haline getirmek için reformlar gerçekleştirmek amaçlanmaktadır. Eğitim uygulamalarında fırsat eşitliği sağlanarak, kimsenin maddiyatsızlık sebebiyle öğretim uygulamalarında eğitim hakkının elinden alınmaması, eğitim sistemindeki zorunlu bağış uygulamalarının kaldırılması, hiç kimsenin yaşamı boyunca eğitim almak adına geç kalmış olarak adlandırılmaması, eğitimin hiçbir dalı ve basamağında, kimsenin önüne set koyulmaması ve başarı durumlarının tek bir kıstas olarak uygulanması düşünülmektedir.

\subsubsection{Insanı Merkeze Alan Çăğdaş Eğitim:}

- Atatürkçü düşünce sistemini, ulusal hassasiyetleri ve evrensel boyuttaki etik değerler sistemini özümseten,

- Bilgiyi aktaran değil, özümseten ve yaşamın içinde uygulamayı temele alan,

- Bireylere özgüven veren, öğrenmeye ve idealizme teşvik eden, cezalandırıcı olmayan ödüllendirici davranan,

- Doğal çevreyle uyumlu bir biçimde yaşayabilen,

- Estetik duyarlılı̆̆ı artmış,

- Geçmişten gelen deneyimleri gelecek kuşaklara taşımayı bilen, geleceği planlamayı ve kurgulamayı öğreten,

- Özgür bir biçimde düşünebilen, yaratıcılığı, yeteneklerin geliştirilmesini ve bilimsel düşünceyi temele alan,

- Yenilik durumlarına açık; paylaşımcılığı, katılımcılığı ve sorgulamayı öngören,

- Vatandaşlık sorumlulukları ve haklarını bilen ve bu haklara sahip çıkan bir eğitim devriminin gerçekleştirilmesi hedeflenmektedir.

4.4.4. Insanı Merkeze Alan Çă̆daş Ĕ̆itim Devrimi: İnsan haklarına saygı duyan, bağnaz yapıdan uzak kalan, sevecen, rasyonel düşünen ve demokrat nesiller yetiştirilmek amaçlanmaktadır.

- Gençleri hayata üretken ve etkin bireyler olarak hazırlamak; sanatın, bilimin, uygarlığın ve kültürün aydınlığından ve değerlerinden faydalanmaları amaçlanmaktadır.

- İlköğretim ve ortaöğretim sisteminde hedef olarak belirlenen başarıya ulaşılabilmesi adına teknolojik, ekonomik ve eğitsel bakımdan gereksinim duyulan desteğin devlet tarafından sağlanıp, eğitim sistemine aktarılmış olan özel ve kamu kaynaklarının ulusal eğitim politikası kapsamında en nitelikli bir biçimde kullanılmasına dikkat edileceği, bu neticede eğitim sisteminin eksikliklerinin giderilmesine yönelik olarak özel girişimci ve yatırımların da devletin sıkı denetimiyle özendirilmesi düşünülmektedir.

- Eğitim planlamaları etkinleştirilerek nitelikli insan gücü kaynaklarından ölçülü bir biçimde yararlanılması, ülkenin tümünde yardımcı personellerin ve öğretmenlerin ihtiyaçlarının dengeli bir biçimde karşılanması ve bu amaç doğrultusunda Devlet Planlama Teşkilatı'nın tekrardan etkinleştirilmesinin sağlanacağına değinilmiştir.

$91 \mid \mathrm{P}$ a g e

WWW.iiste.org 


\subsubsection{Nitelikli ve Çă̆daş Ĕ̆itim:}

Laik ve demokratik eğitim ortamları: Okulların çatısı altında huzurlu ve güvenli eğitim ortamının sağlanıp, yurtlarda ve okullarda cemaat baskılarına, laik olan milli eğitim esaslarına aykırı yapılara son verileceğine; MEB' in cemaatlerin etkisi altında kalan bir yapı olmaktan çıkarılarak, eğitim kadrolarının her seviyesinde liyakate dikkat edileceğine; insan hakları, demokrasi ve hoşgörü kültürünü okullarda yaşatarak öğrenme ve özümseme adına demokrasi bilinci konularının okullarımızda uygulamalı ders şeklinde verileceğine değinilmiştir.

Öğrencilere uzman rehber öğretmenler destekleri: Bu konu üzerine eksik kalan kadroların ve teknik altyapı sistemlerinin yeterli olmasına gayret edileceğine temas edilmiştir.

Her ortaöğretim öğrencisine en az bir yabancı dil öğretilmesi: Modern yabancı dil eğitimlerine özen gösterilerek, mesleki veya akademik liseleri bitiren bireylerin en az bir yabanc1 dili iyi derecede bilmelerinin sağlanarak nitelikli eğitim verilmesi hedeflenmektedir.

Güneydoğu ve Doğu Anadolu'da nitelikli eğitim: Başta Güneydoğu ve Doğu Anadolu Bölgeleri olmak üzere bilhassa kırsal kesimde, yoksul bireylerin yoğun olduğu yerlerde (YİBO) Yatılı İlköğretim Bölge Okullarının sayılarını arttırmanın hedeflendiğine değinilmiştir.

Zorunlu durumlarda taşımalı eğitim sistemi: Eğitim kurumlarında öğretim gören çocuk ve gençlerin yaşamaya devam ettikleri yerleşim yerlerinde eğitim almalarının esas olması, fakat istisna olan uygulamalarda taşımalı eğitim sisteminin uygulanması parti gündemindedir.

Yetişkin bireylerin sürekli eğitim imkânlarının yaygınlaştırılması: Olağan eğitim döneminde yeterli düzeyde eğitim alma şansı elde edememiş ya da okur-yazar olmayan yetişkin bireylere eğitim verme amacı ile ilgili üniversite ve belediyeler ile beraber devam ettirilecek yetişkinlere yönelik sürekli eğitim programlarının gerçekleştirileceğine vurgu yapılmıştır.

Okuma yazması olmayan birey kalmayacak: Seferberlik kapsamında okuma ve yazma kurslarıyla, ülkede okuma ve yazmayı bilmeyen bireyin kalmaması adına çalışılacağına değinilmiştir.

Din kültürü ve ahlak eğitimleri verilecek: Özgürlüklerin sadece laik eğitim sistemlerinde değer ve anlam kazanabileceği ve süreklilik arz edebileceğine değinilmiştir. Eğitim sisteminin laik bir plana oturtulup, öğretim birliği içerisinde yürütülmesi gerekmektedir. Yeniliğe, bilime ve değişim durumlarına açık, gelecek vizyonuna sahip, demokratik bir devlet yapısı ve çağdaş bir toplum yapısının oluşturulmasına çalışılmaktadır. Din eğitimlerinin bireylerin inanç dünyalarını geliştiren, çağdaş gelişmelere açık, ahlaki ve manevi değerleri zengin hale getiren, doğa ve insan sevgisini çoğaltan nitelikte olacak; siyasi amaçlar ile istismara yol açmayacak bir biçimde olacağına; dini duyguların istismar edilip, tarikat veya cemaatlerin eğitim sistemlerini kuşatmasının önüne geçileceğine; İmam-Hatiplerde verilen eğitimin, din görevlisi ihtiyacı sayısına uygun olarak düzenleneceğine; ilköğretim ve ortaöğretim okullarında işlenen Din kültürü ve ahlak bilgisi derslerinin anayasanın planladığı amaçlara uyan bir müfredat ile verileceğine ve Diyanet İşleri Başkanlığı' na bağlı kuran kursları dışındaki kurslar ya da benzeri hizmetlere izin verilmemesine, bütün kuran kurslarının etkin bir biçimde denetlenmesine özen gösterilmesine değinilmiştir.

Azınlıklara din adamı yetiştirme imkânı: Azınlık vatandaşların dini gereksinimlerini karşılamak adına yüksek seviyede din adamı yetiştirilmesi için ilgili devlet üniversitelerinde ilahiyat fakültelerine bağlı olacak biçimde eğitimin genel ilke ve esasları çerçevesinde yüksekokulların açılacağına dikkat çekilmiştir.

$\mathrm{Bu}$ ana başlıklar ile beraber CHP'nin parti programında eğitim ile ilgili olarak; okul öncesindeki iki yıllık eğitimin zorunlu hale getirileceğine, çalışan annelerin çocuklarına eğitimde önceliklerin olacağına, eğitime katılıma destek ödemesi yapılacağına değinilmiştir. Aynı zamanda 10 yıl süren zorunlu ve kesintisiz temel eğitime geçilmek istendiği; temel eğitimde 9. ve 10. sınıflarda mesleki yönlendirme programlarının olacağına da değinilmiştir. Yükseköğretimin yeniden yapılandırılacağına, üniversiteye giriş sisteminin güncelleneceğine, YÖK'ün kaldırılarak üniversitelerarası kurulun etkinliğinin arttırılacağına, lisansüstü öğrenim görenlerin desteleneceğine, öğretmene saygının artacağına ve atama sisteminin yeniden düzenleneceğine, öğretmensiz derslik bırakılmayacağına da ayrı ayrı değinilmiştir (CHP Parti Programı, 2018, s.293-306).

$92 \mid \mathrm{P}$ a g e

wWw.iiste.org 


\subsection{IYI Partinin Ĕgitim Politikaları}

İYİ Parti'nin parti programında “Eğimde genel olarak yapılacaklar” başlığı altında eğitim politikaları ile ilgili olarak özetle şunlara değinilmiştir (İYİ Parti Programı, 2018):

- Türkiye'nin en önemli sorunlarından birisi olan eğitim problemlerinin "Eğitim Seferberliği” ile üstesinden gelineceğine, Türkiye'nin 10 yıl içerisinde dünyanın örnek göstereceği ülkelerden biri olacağına dikkat çekilmiştir.

- Çocukların Atatürkçü, çağdaş, milli bilince sahip olan iyi bireyler olarak yetiştirilmesi ve iyi okullar bünyesinde, iyi eğitimler almaları amacı ile eğitim kurumlarının günümüz gereksinimleri arasında olan bilimsel, teknolojik, kültürel ve sosyal alt yapıya sahip olmasına çalıșılacağı aktarılmıştır.

- Eğitim sisteminden başlanılarak, Cumhuriyetimizin oluşumunda kurucu değerlere sahip öğelerin tesisinin temin edilerek, ilk olarak milli değerlerimizin sembol birimi olan milli bayramların coşku içerisinde kutlanması amaçlanmaktadır.

- Kendi branşlarında iyi yetiştirilmiş; sporu, sanatı ve demokratik değerleri bir hayat felsefesi olarak benimsemiş, dünyadaki gelişmeleri takip edecek ölçüde yabancı dil bilgisi olan ve bilgi birikimlerini öğrencilere aktarmak adına mesleğine âşık öğretmenlerin okutulacağı "Öğretmen Akademileri" kurularak öğretmenlerin yetiştirilmesi sürecinde yeni bir çağ açılacağına değinilmiştir. Teknik öğretmen ihtiyacına göre akademilerin yeniden yapılandırılarak meslek okullarına öğretmen istihdamlarının sağlanacağına ve öğretmen liselerinin tekrardan eski kimliklerine döndürüleceğine dikkat çekilmiştir.

- Öğrencilerin; özgür, yaratıcı, eleştirel bir biçimde düşünebilme; birlikte çalışma ve birlikte yaşama becerilerini geliştirilecek araştırma, problem çözme, sorgulama, teknolojiyi etkin kullanma ve girişimci yapılarıyla analiz, sentez, değerlendirme özelliklerine ve milli bilince sahip, doğaya, insan haklarına ve çevreye karşı duyarlı, "iyi insan” olarak yetiştirilmelerinin amaçlandığ 1 aktarılmıştır.

$\mathrm{Bu}$ amaçla;

- Malî, akademik, idarî ve sosyal düzenlemeler ile öğretmenliğin cazip ve saygın bir meslek haline geleceğine; öğretmenlerin ücret, maaş, emeklilik hakları ve sosyal hakları bakımından yıllardır çözüm bekleyen problemlerinin çözüleceğine dikkat çekilmiştir.

- Bakanlığın bütün yapılarında ve okullarında kadın yöneticilerin sayısının arttırılmasını sağlanıp, okullarda \%50 oranında kadın yönetici olmasının hedeflendiği aktarılmıştır.

- Dilin kirlenmesinin önüne geçileceğine değinilmiştir.

- Eğitim politikalarına partilerin üstünde bir bakış getirilerek, (EPKK) Eğitim Planlama ve Koordinasyon Kurulu oluşturulup bütün paydaşların katılımı sağlanarak uzun vadeli eğitim politikaları oluşturulacağı; EPKK içerisinde öğrenci temsilcileri, öğretmenler, sendikalar, üniversiteler, ticaret ve sanayi odaları temsilcileri, veli örgütleri temsilcileri ve barolar gibi STK temsilcilerinin bulunacağı aktarılmıştır.

- Eğitim sisteminin okul öncesinden başlayarak, yükseköğretim basamağına kadar, ekonominin değişim gösteren talepleri ve toplum refahı arasında denge sağlayacak bir biçimde esnek ve dinamik bir yapıya sokulacağ

- Eğitimin bütün basamaklarında sporun ve sanatın aktif bir biçimde öğrencilerin hayatının bir parçası olmasına gayret edileceği; zorunlu eğitim basamaklarını tamamlayan tüm öğrencilerin sporun en az bir branşıyla ilgilenmesinin sağlanacağı vurgulanmıştır.

- Eğitimin eğitimcilere ait olacağı ve tüm siyasi müdahale ve mülahazanın dışında kalacağına değinilmiştir.

- GSYİH'nin eğitime ayrılmış olan payının dereceli bir biçimde uluslararası standartların düzeyine getirileceğine temas edilmiştir.

- İl ve ilçe milli eğitim müdürlüklerinin eğitim kalitesi ve etkin icraat yönünden rehber makamlar olmasının hedeflendiğine; eğitim kadroları ve kurumlarının gözlem ve rehberlik açısından bilimsel ilkeler ölçüsünde denetleneceğine dikkat çekilmiştir.

- İnsan temelli bir eğitim felsefesinin uygulanması ve oluşturulmasının sağlanacağına değinilmiştir.

- Kadınların eğitilmesine önem gösterilerek etkili yaygın eğitim programlarının uygulamaya alınacağına; bu neticede Halk Eğitim Merkezlerinin daha etkin kullanılarak belediyelerin sürece etkin katılımının sağlanacağ1 ifade edilmiştir.

- Okul yönetimlerinin "başöğretmenlik" ve "müdürlük" formatında ikiye ayrılarak eğitim kısmıyla başöğretmenlerin idari işler kısmıyla da müdürlerin ilgileneceğine dikkat çekilmiştir. 
- Öğrencilerin Türkçeyi güzel, akıcı ve doğru bir şekilde kullanmasına dikkat edileceğine, bununla beraber bütün öğrencilere zorunlu eğitim sürelerinde en az bir yabancı dili öğrenme imkânı sunulacağına değinilmiştir.

- Finansal okuryazarlık, temel bilgisayar programlama uygulamaları, hukuki/siyasi okuryazarlık, el becerileri, hitabet gibi hayat ile ilgili konularla ilkokuldan itibaren tüm eğitim basamaklarında programlama ve kodlama derslerinin de olduğu yeni müfredatların uygulanacağı aktarılmıştır.

- Temel eğitimden geçmiş öğrencilerimizin PISA sınav sonuçlarının eğitim sistemimiz adına kaygı verici olduğuna; bu kötü duruma son vermek adına gerekli tedbirlerin uygulanacağına dikkat çekilmiştir.

- Türkçe'nin sosyal medyada, ticaret, sanat, bilim ve diğer tüm alanlarda, estetik açıdan kaliteli kullanılmasının sağlanıp, kavram ve terimlerimize hâkim olunmasının yanında, Türkçe'nin iletişim ve bilim dili olması adına paydaşlar ile birlik ve beraberlik içerisinde gayret gösterileceğine değinilmiştir.

- Yurt dışında yaşamakta olan Türk çocuklarının kültür yapılarını koruma ve geliştirmeleri adına öğrenci değişim uygulamaları gibi diğer örgün ve yaygın eğitim firsatlarının çoğaltılacağına, ilgili ülkeler ile karşılıklı anlayış içinde ve iyi ilişkiler kurularak Türk kültürü ve Türkçe derslerinin seçmeli ders şeklinde okutulması adına gerekli desteğin verileceği ifade edilmiştir.

$\mathrm{Bu}$ başlıklar haricinde okul öncesi eğitim sistemi, temel eğitim sistemi, meslek okulları, özel eğitim kurum ve kuruluşları, yaygın eğitim ve yükseköğretim sistemi başlıklarında eğitim politikaları IYİ Parti programında ayrı ayrı ele alınmıştır (İyi Parti Programı, 2018).

\subsection{Saadet Partisinin Ĕ̈itim Politikalart}

Saadet Partisi'nin parti programında (2018) "Devletin Nitelikleri ve Illkeler” teması adı altında "Ĕ̈itim ve Öğretim” başlı̆̆ında eğitim politikaları ile ilgili olarak özetle şunlara değinilmektedir:

- Her bireyin eğitim alma hakkı bulunduğuna; eğitim sisteminin bütün basamaklarının devlet okullarında parasız olması gerektiğine; ilk, orta ve liselerde eğitimin mecburi olması gerektiğine; mesleki ve teknik eğitim sisteminden tüm bireylerin faydalanabilmesinin sağlanmasına, yükseköğretimin liyakate göre bütün bireylere eşitlik ve açık olmasının sağlanmasına temas edilmiştir.

- Eğitim uygulamalarının insanın kişiliğinin tam olarak gelişmesine, temel özgürlüklerin ve insan haklarına saygının güçlenmesine katkı sağlayacak bir nitelikte olması gerektiği, tüm gruplar ve insanlar arasında dostluğu, hoşgörüyü, anlayışı ve barışı motive etmesi gerektiği vurgulanmıştır.

- Saadet Partisi; eğitim, öğretim ve terbiye, insan hakları, demokrasi ve özgürlüklerin değerli olduğuna, bununla beraber uluslararası rekabet zincirinin oldukça hızlandığı bu dönemde gereksinim duyulan insan kaynaklarının en verimli bir biçimde yetiştirilmesi amacına yönelik olduğuna dikkat çekmiştir.

- Eğitim ve öğretimler ile bireylerin sadece beceri ve bilgi ile donatılmasının yetersiz olduğuna; insanlara birtakım değerlerin de verilmesi gerektiğine, bu sebeple de Saadet Partisi'nin "eğitim ve öğretimde terbiye" unsurunu önemsediği aktarılmıştır.

- İdeolojik ve siyasi mülâhazalar ile sürekli değiştirilen eğitim sisteminin artık başlı başına bir problem haline dönüştüğ̈̈; son 12 yıl içerisinde kadrolar ve yöneticilerin sürekli değiştirildiği; tabletlerle, akıllı tahtalarla ve binalarla uğraşıldığına ama eğitimde kalite ve müfredatın ise değişmediğine dikkat çekilmiştir. Bu sebep ile eğitim sistemindeki kalitenin azaldığı, eğitimde bulunan firsat eşitliğinin yok olduğu, hatta ve hatta gençlerin eğitim haklarının ellerinden alındığı aktarılmıştır.

- Yeni nesillerin kendi kendilerine karar veren, özgüven sahibi, geçmişlerini bilen ve imkânlardan haberdar olan, küresel gerçekleri bilip, evrensel değerler ve anlayışlarla bütünleşmiş bir biçimde donatılmadıkları takdirde toplumun özlemlerini gerçekleştirmenin mümkün olmadığına değinilmiştir. Bu sebeple Saadet Partisi, ilmî gereksinimlere uyan bir eğitim devrimini programına dâhil etmiştir. Bilim uygulamaları, araştırmalar, eğitim ve öğretimin serbest olacağı, Anayasaya ve insan haklarına aykırı bulunmayan tüm düzey ve alanlarda eğitim ve öğretim kurumlarının açılabileceği, inanç esaslarına ve insan haklarına aykırı bir biçimde konmuş engellerin ortadan kaldırılmasına değinilmiştir. Eğitim veren kurumlarda demokrasi ve "İnsan Hakları" ile "Din Kültürü ve Ahlâk Bilgisi” derslerinin okutulmasının zorunlu tutulacağı da ifade edilmiştir.

- Gençlerimize özgüven kazandırmak ve tarihleri ile bağlarını arttırmak adına "Divan Edebiyatı" ve "Bilimler Tarihi" derslerinin müfredat bünyesine dâhil edileceğine değinilmiştir.

$94 \mid \mathrm{P}$ a g e

WWW.iiste.org 
- Saadet Partisi'nin 4+4+3 zorunlu eğitim ve öğretim modeli ile faydalı bir eğitim verileceğine inancının tam olduğu, zorunlu eğitimin II. ve III. kademesinin teknik ve mesleki eğitim sistemine geçişi kolaylaştıran bir şekilde düzenleneceği ifade edilmiştir.

- Yükseköğretim sistemine geçişte firsat eşitliğinin temele alınacağı ifade edilmiştir. Teknik ve mesleki eğitim ile meslek edindirme kursları ve çıraklık eğitiminin geliştirileceği ifade edilmiştir.

- Din eğitimleri, 18 yaşına kadar velilerin izni ile 18 yaşından itibaren de bireylerin kendi isteğine bağ lı bir şekilde her kademede serbest olacağına; devletin ilköğretim ve ortaöğretim sistemlerinde müfredatı belirleme, standartları oluşturma ve denetleme ile sorumlu olacağına dikkat çekilmiştir.

- Üniversitelerde yaşanan kaynak sorunları çözülerek, aslî görevleri olan bilgiyi üretme ve yayma görevini sağlıklı bir biçimde yapabilmeleri adına idari yapının özgürlüğü sağlanarak köklü bir yükseköğretim devriminin gerçekleştirilmesi planlanmaktadır.

- Üniversite kurulmasının serbest bırakılması Saadet Partisi’nin gündemindedir. Devletin de bu durumda yükseköğretim ile ilgili plânlama yapma, standartlarını belirleme, yükseköğretim kurumlarındaki faaliyetlerin kanunlara uygun olup olmadığını denetleme ile yükümlü olacağına değinilmiştir.

- Yükseköğretim Kurulu kaldırılarak, onun yerine yükseköğretim ile ilgili devlete düşen görevler ve üniversitelerin içindeki bağı sağlamak adına bir üst kurulun oluşturulması istenmektedir.

- Özel gereksinimli bireylerin nitelikli eğitim almasına özen gösterilerek, bu özen için kurumların geliştirilmesinin destekleneceğine, üstün yetenekli çocukların tespit edilmesi ve özel eğitim imkânlarından faydalanmalarının sağlanacağına, halk eğitimi uygulamalarına özen gösterilerek, bu konu ile ilgili STK'lar ve yerel yönetimlerin önünde duran engellerin kaldırılacağına vurgu yapılmaktadır (Saaadet Partisi Programı, 2014).

\subsection{Halkların Demokratik Partisinin Eğitim Politikaları}

HDP'nin parti programında (2015) her bireyin ait olduğu kültürden kaynaklanan farklılıkları dikkate alan bir eğitim politikası amaçlanmaktadır. HDP, anadilde eğitim verilmesinin tüm vatandaşların hakkı olduğunu, bu sebeple eğitim sisteminin tüm kademelerinde, kamu kurum ve kuruluşlarında anadil kullanmanın serbest olması, kamusal alanda anadilde hizmetlerin sunulması gerektiğini savunmaktadır. Türkiye'de konuşulan bütün lisanslar ile ilgili üniversitelerde kürsülerin açılmasını, meslek liselerinin ileri teknoloji ve üstün kalitede eğitim ve hizmet sunacak kurumlara dönüştürülmesini, temel eğitim gibi anaokulların da zorunlu olması, eğitim sistemlerinin tüm basamaklarında sınavsız geçişlerin olmasını savunmaktadır. Müfredat oluşturulurken bilimsel yöntem ve tekniklerden faydalanarak eğitimcilerin önerileri ile eğitim meclisinin talepleri dikkate alınarak, cinsiyetçi olmayan öğrenci ve çalışanların nitelikli eğitim alma haklarının savunulması, engellilerin önündeki engelleri kaldıracak yeni bir sistemin yapılandırılması gerektiğine vurgu yapmaktadır. Merkezi ve otoriter bir yönetim yerine halkları barışık tutan demokratik ve yerelden yönetilen eğitim meclislerinin her ilde inşa edilmesi gerektiğini dile getirmektedir. Zorunlu Din dersleri ile Diyanet'in kaldırılması, Alevi vatandaşların eşit yurttaşlık isteklerinin temini, cem evlerinin ibadethane olarak kabul görmesini, niteliksiz ve tekçi eğitimin kabul edilmeyerek, tüm bireylere yaşam boyu ücretsiz, demokratik, bilimsel, eşit, ana dillerini kullanabilecekleri bir eğitim fırsatının verilmesini istemektedir. Eşitsizlik temelli, rekabetçi bir eğitim sisteminin reddedilmesi, YÖK'ün kaldırılarak üniversitelerin özgürleştirilmesi, üniversite eğitimin ücretsiz ve tüm vatandaşlara açık olması gerektiğini, üniversiteye yerleşme amacıyla yapılan sınavların, öğrencilerin yeterliliğini ölçmede yetersiz kalması gerekçesiyle uygulamadan kaldırılmasını, üniversite öğrencilerine yönelik ücretsiz yurt olanaklarının arttırılmasını, zorunlu ihtiyaçlarının da devlet tarafından karşılanması gerektiğini savunmaktadır. Eğitimi tüm milliyetçi, ayrıştırıcı, toplumsal ve cinsiyetçi öğelerden ayıklayacak, bu anlamda başarılı olmak içinde ilk ve ortaöğretimde demokrasi ve insan hakları derslerinin önem kazanmasını sağlayacak bir eğitim modeli tasarlanmak istemektedir (Halkların Demokratik Partisi, 2015).

\subsection{Siyasi Partilerin Ĕ̆itim Politikalarının Teori ve Uygulama Açısından İncelenmesi}

$\mathrm{Bu}$ başlık altında siyasi parti eğitim politikalarını 2002 yılından beri uygulamaya koyabilen tek parti olan AK Parti'nin uygulamaları, 2018 AK Parti Genel seçim beyannamesine göre incelenmeye çalışılacaktır.

AK Parti, tüm çocukların eğitim ve öğretim imkânlarına eşit şartlarda ulaşmalarını; çağın gereksinimi olan beceri, bilgi, davranış ve tutumları yenilikçi ve girişimci bir bakış açısı ile edinmelerini; sorumluluk ve özgüven sahibi olmalarını; mutlu ve sağlıklı bireyler şeklinde yetiştirilmelerini kendisine temel görev olarak

95 | P a g e

Www.iiste.org 
atfetmiştir. Bu tür beyanları ile AK Parti'nin seçim bildirgelerinde yer alan konuları eğitim sistemine yansıtma gayreti içinde olduğu görülmektedir. Bunun için sosyal devletin getirdiği anlayış ile eğitim sisteminin tüm bireyler adına erişilebilirliğini sağlanmıştır. Veliler adına bazı zamanlar ekonomik bir yük olan ve öğrenciler için de sıkıntı oluşturan ders kitapları artık ücret alınmadan öğrencilere verilmektedir. Bu projenin uygulanması için toplamda 4.6 milyar TL'nin üstünde bir ödeme ile 2.65 milyar adet ders kitabı ücretsiz olarak öğrencilere dağıtılmıştır. 2003 yılı itibari ile resmî okullarda yürütülen "Ücretsiz Ders Kitabı Dağıtımı" projesi kapsamına 2014-2015 döneminden itibaren özel okullar da dâhil edilmiş ve talep oluşturan özel okulların tümüne ücretsiz ders kitapları dağıtılmıştır. Bununla beraber ihtiyacı olan ailelere çocuklarını düzenli bir şekilde okula göndermeleri kaydıyla her ay eğitim ödemesi yapılmaktadır. 2003 yılı itibari ile başlatılan şartlı eğitim yardımları ile hem çocuklar eğitim-öğretime dâhil edilmiş hem de bu yardımlar nakdî bir biçimde annelere aktarılarak onların aile kurumunda daha çok söz hakkına sahip olması amaçlanmıştır. 2003-2017 yıllarında toplamda 26.7 milyon çocuk için annelere 5.8 milyar TL ödeme aktarılmıştır. Bu ödemelere halen devam edilmektedir. Bu hususta pozitif ayrımcılık yapılarak, ilköğretim sistemine devam eden kız öğrencilere 40 TL, erkek öğrencilere 35 TL; ortaöğretim sistemine devam eden kız öğrencilere 60 TL, erkek öğrencilere de $50 \mathrm{TL}$ aylık ödemeler gerçekleştirilmektedir. Kız öğrencilerin eğitimi üzerinde titizlikle durulmaktadır. Uygulanan politikalar neticesinde 2002 yılı itibari ile \%88 seviyesindeki ilköğretim düzeyi kız çocuklarının net okullaşma oranının, 2017-2018 eğitim-öğretim yılı itibari ile \%95,76 seviyesine çıktığı görülmektedir.

Yaşam boyu öğrenme faaliyetleri ile topluma yönelik olarak eğitim hizmeti uygulamalarının devam ettiğ görülmektedir. Hedef, okuma-yazma öğrenmeyen tek bir vatandaşın kalmaması olarak planlanmıştır. 2003 ve 2015 yıllarını kapsayan dönemlerde 2.901.520’i kadın olmakla beraber, toplamda 4.150 .000 vatandaşın okuma-yazma öğrendiği bilinmektedir.

Verilen burs miktarları sembolik rakam olmaktan çıkartılıp, öğrencilerin gerçek düzeyde ihtiyaçlarını karşılayabilir düzeye getirilmiştir. 2002 yılı içerisinde 13 TL olan ilköğretim ve ortaöğretim bursu, 2017 yılı itibari ile 204 TL bandına yükseltilmiştir. Özel okulların erişilmez olduğu algısı kırılmış, 2014 yılı itibarı ile başlatılan uygulamayla 340 bin ögrenciye kademesine bakılarak y1llı 2.860 TL ila 4.000 TL arasında değişen miktarda özel okul desteği sağlanmıştır.

AK Parti eğitim sisteminde ortaya koyduğu reform düzeyindeki düzenlemeler ile 28 Şubat'ın izlerini eğitim sisteminden uzaklaştırmıştır. Cumhuriyet tarihinde kara bir leke olarak duran başörtüsü yasağ uygulamasına son vererek öğrenci ve öğretmenlerin mağduriyetleri ortadan kaldırılmıştır. Daha özgür ve demokratik bir eğitim sistemi oluşturulması amacı ile farklı lehçe ve dillerin öğrenimi serbest bırakılmıştır.

AK Parti, Türkiye'deki gençleri tek tip eğitim sistemi çemberinden kurtararak, farklı görüş ve inançlara saygı duyan, dünyadaki gelişmeleri takip eden, ileri düzeydeki teknolojileri kullanabilen vatandaşlar olmasına önem vermektedir. Eğitimdeki köklü değişiklikler ile 4+4+4 sistemine geçiş yapılmıştır. Eğitimdeki müfredat anti-demokratik içeriklerden muhafaza edilip, çağın ihtiyaçlarına göre düzenlenmiştir. Tek tip eğitim anlayışlarına karşı; öğrencilerin hukuk ve adil bir toplum bilinci kazanması amacı ile "Hukuk ve Adalet” dersi müfredata alınmıştır. Gençlerin İslam dinini doğru kaynaktan öğrenmesi adına "Siyer” ve “Kur'an-1 Kerim” dersleri de seçmeli ders olarak eğitim müfredatına eklenmiştir.

Eğitimde sadece fiziksel yatırımların değil, çağın istediği teknolojik altyapı sistemlerinin kurulması ve müfredatların geliştirilmesi adına büyük bir gayret gösterildiği görülmektedir. (FATİH), Eğitimde Fırsatları Artırma ve Teknolojiyi İyileştirme Hareketi projesi bu sebeple uygulamaya alınmıştır. Teknolojiye erişilebilirliği arttırmak adına öğrenci ve öğretmenlere 1.437 .800 adet tablet dağıtılmıştır. FATİH Projesi kapsamında okullara 432.315 akıllı tahta kurulmuştur.

Çocuk gelişiminde en önemli dönemlerden birisi konumundaki okul öncesi eğitim hizmetleri arttırılmıştır. Tüm çocukların zorunlu eğitimlerine başlama öncesinde en az bir yıl boyunca okul öncesi eğitim kurumlarına devam etmesi temel hedef olarak benimsenmiş, okul öncesi eğitim uygulamaları tamamıyla ücretsiz yapılarak tüm çocukların bu eğitimden istifade etmeleri sağlanılmıştır.

Gençler adına sosyal bilimlerin bir hayli önemli olduğu anlaşılmış ve buna bağlı olarak, Türkiye'de ilk kez "Sosyal Bilimler Liseleri” açılmıştır. 2018 yılı neticesinde Türkiye’de 87 Sosyal Bilimler Lisesi öğrencilere eğitim hizmeti sunmaktadır. Sanat ve sporla iç içe insanların yetişmesi, öğrencilerin ilgi ve yetenek alanlarına göre eğitim almaları adına "Güzel Sanatlar ve Spor Liseleri” kurulmuştur. 2017-2018 eğitimöğretim yılı itibari ile 81 Güzel Sanatlar Lisesi ve 70 Spor Lisesi öğrencilere hizmet vermektedir.

$96 \mid \mathrm{P}$ a g e

WWW.iiste.org 
Ekonominin temel gereksinimi olan ara eleman ihtiyacını karşılamak ve nitelikli insan gücü kapasitesini arttırmak amacı ile çok yönlü çalışmalar gerçekleştirildiği dile getirilmiştir. Bu neticede 2002 yılından önce meslek liselerinin önüne koyulan ideolojik engeller ortadan kaldırılmıştır. Özel teknik ve mesleki eğitim okullarında okuyan öğrencilerin alanlarında maddi desteğe ihtiyacı olabileceği düşüncesi ile kendilerine 4.590 TL ila 6.900 TL arasında maddi katkılar gerçekleştirilmiştir. 2016 yılı itibari ile bu destekten fayda sağlayan öğrenci sayısı 41.017'dir. Meslek liselerinden mezun olan öğrencilerimize yükseköğretim sistemine geçiş durumlarında uygulanmakta olan katsayı adaletsizliği giderilerek firsat eşitliği sağlanmıştır.

Üniversite yatırımları öğrencilerin yaşadıkları illerde yükseköğretime dâhil olabilmeleri ve bilimsel çalışmaların tüm ülke geneline eşit bir şekilde yayılması amacıyla katlanarak çoğalmıştır. Yükseköğretim uygulamalarının tüm öğrenciler adına ulaşılabilir olması gerçekleştirilmiştir. 81 ilde üniversiteler açılması sağlanılmış ve üniversitelerin sayısı böylece 186'ya çıkmıştır. Savunma faaliyetlerinde donanımlı, bilinçli, uygulanabilir yeni metotları üreten bireyleri yetiştirecek “Milli Savunma Üniversitesi” kurulmuştur

Ak Parti iktidarında yükseköğretim sistemlerinde net okullaşma oranı \%13 seviyesinden \%43 seviyelerine çıkmıştır. Bu durum neticesinde 2002-2003 eğitim-öğretim yılı içerisinde 1.9 milyon seviyesinde olan öğrenci sayıları 2016-2017 eğitim-öğretim içerisinde 7.2 milyon seviyesine çıkmıştır. Üniversitede okuyan öğrencilerinin maddi imkânsızlıklarını en az seviyeye indirmek amacıyla, YURTKUR dâhil olmak üzere yükseköğretim sistemine ayrılmış olan 3 milyar TL olan bütçe 11 kat artarak 41 milyar TL seviyesine yükseltilmiştir. Bu artış ile merkezi yönetim bütçesindeki \%2.5 olan payda \%5.4 seviyesine ulaşmıştır.

Özel eğitim gereksinimi olan bireylerin rehabilitasyonu ve eğitimlerine ilişkin 2006-2018 yılları arasında milli eğitim bütçesinden yaklaşık 15 milyar TL kaynak yaratılmıştır. Özel eğitim gereksinimleri olan kursiyerler ve öğrenciler adına taşıma hizmeti uygulamaya alınmıştır. Bu neticede, 2004-2005 eğitimöğretim yılı içerisinde 6.901 özel gereksinimli kursiyer ve öğrenci taşıma hizmeti alırken, bu sayının 20172018 eğitim-öğretim yılında 90.000’e ulaştı̆̆ 1 görülmektedir.

2002 yılı ve sonrasında günümüze kadar gelen süreçte gerçekleştirilen öğretmen atamaları ile Cumhuriyet tarihindeki en kapsamlı eğitim istihdamı gerçekleştirilmiştir. Bu istihdam ile beraber öğretmenlerin yaşam standartlarının ve mesleki olanaklarının da iyileştirilmesi yönünde kapsamlı düzenlemeler yapılmıştır. AK Parti 16 yıl süren iktidarı boyunca 584.288 öğretme ataması gerçekleştirmiştir. Toplamda öğretmen sayısını 923.321'e çıkarmıştır. Engelli öğretmenleri de istihdam sürecine katarak, 3.203 engelli öğretmen ataması yapılmıştır. Spor ve sporcuların her zaman yanında durulmuştur. Milli sporcuların da istihdama dâhil edilmesi ile 950 milli sporcu öğretmen olarak atanmıştır. Bu atamalar ile ülke genelinde öğretmen normu doluluk seviyesi \%90,6 olmuştur (AK Parti Seçim Beyannamesi, 2018).

\section{Tartışma ve Sonuç}

$\mathrm{Bu}$ araştırmada Türkiye'deki siyasi partilerin güncel eğitim politikaları parti programları bağlamında incelenmiştir. Araştırma neticesinde parti programları incelenen 6 siyasi partinin de eğitime yönelik farklı bakış açıları olduğu sonucuna ulaşmıştır. Mevcut araştırmalarda da (Korkmaz, 2018; Altınışık ve Songür, 2016) hem seçim bildirgelerinde, hem de parti programlarında siyasi partilerin eğitim söylemlerinin birbirinden farklı olduğuna değinmişlerdir. Berber (2001) gerçekleştirdiği araştırmada 18 Nisan 1999 seçimlerine katılmış olan 20 siyasi partinin eğitim programlarını karşılaştırmış, benzerlik ve farklılıkları ortaya çıkarmaya çalışmıştır. Bu araştırmaya göre, partilerin eğitim politikaları ve ideolojik görüşleri arasında tutarsızlıkların oldu görülmektedir. Ayrıca siyasi partiler, parti programlarında bulunan eğitim politikalarını iktidar dönemlerinde gerçekleştirememişlerdir. Mevcut araştırma bulgularında ise sonuç bu durumun tam tersidir. 2002 yılından beri iktidarda olan AK Parti programında eğitim ile ilgili vaat ettiği politikaların birçoğunu gerçekleştirmiş ve gerçekleştirmeye devam etmektedir.

Araştırmada bulgularında incelenen parti programlarında "eğitim" konusu araştırmanın merkezine alındığında AK Parti ve CHP'nin parti programlarının diğer partilerin programlarına göre nispeten daha özenli bir şekilde hazırlandığı ve bu partilerin eğitim politikalarında gerçekleştirilmesi muhtemel olan vaatlere daha fazla yer verildiği görülmektedir. Dünya üzerindeki ülkelerin eğitim çalışmaları ve uygulamaları, ülkeyi yönetmeye aday ve yöneten siyasi partilerin (iktidar ve muhalefet) politikaları bağlamında çeşitlenmektedir. Partilerin eğitim politikalarının temel yapı unsuru da siyasi partilerin mevcut ideolojileridir. $\mathrm{Bu}$ ideolojiler ile belirlenen politikalar da parti programlarında belirtilmektedir. Şişman (2007) her siyasi görüşün kendi ideolojik görüşlerini gelecek kuşaklara aktarmak isteyeceğini ve hiçbir

97 | P a g e

WWW.iiste.org 
siyasi görüşün kendine düşman bireyleri yetiştirmek istemeyeceğini dile getirmiştir (s.98).

Siyasî partilerin parti programlarındaki eğitim politikalarına bakıldığında genel olarak Türkiye'de üç ana siyasal eksen olan siyasal islamî partiler, merkez sağ partiler ve merkez sol partiler arasında, bulunduğu politik alan itibariyle mutlak bir berraklığın olmadığı görülmektedir... Söz konusu bulanıklığın ana nedeninin siyasi partilerin, daha çok oy alma refleksi ile felsefe kaygısı gütmeden, popüler taleplere ya da moda trendlere göre hareket etme eğilimi olduğu söylenebilir (Usta, 2015). TEDMEM (2018) ise siyasi partilerin seçim bildirgelerini incelediği araştırmasında partilerin eğitim sistemine yaklaşımlarının hak temelinde olmasının umut verici olduğunu dile getirmiştir. Demokratik sistemlerin doğası gereğince bütün siyasi partilerin belli bir ideoloji ile politika önerilerini sunduklarını, bu neticede de siyasi partilerin eğitim sistemine temel yaklaşımlarının farklılık gösterdiğini de ifade etmiştir. Gürsoy ve Karaboğa (2015) siyasi partilerin eğitim ile alakalı görüşleri ve vaatlerini değerlendirildiği araştırmada, siyasi partilerin eğitime bakış açılarında savundukları siyasi ideolojiler ve kimliklerini belirleyen unsurların ön planda olduğunu belirlemişlerdir. Siyasi partilerin eğitim görüşlerindeki benzerlik ya da farklılıklar, ideoloji bağlamında benzeştikleri ve ayrıştıkları kısımları yansıtmaktadır. Oysaki siyasi partilerin eğitim politikalarının siyaset odaklı değil de pedagoji odaklı olması ve bilimsel veriler 1şı̆̆ında geliştirilmesi çok önemlidir. Eğitim politikalarının ideolojik bir yapı ile bireyleri biçimlendirme aracı olarak görülmesi toplumsal sorunlara da temel oluşturmaktadır.

Mevcut araştırma bulgularında AK Parti’nin parti programındaki eğitim politikaları incelendiğinde, eğitim yatırımların arttırılmasına yönelik çalışmaların planlandığı, eğitimin diğer tüm gelişim alanlarından ön planda tutulacağı ve bu alandaki zaafların ortadan kaldırılacağı açıklanmıştır. AK Parti programlarında da belirttiği üzere, Türkiye eğitim açısından ciddi bir karmaşa içerisindedir. Bu karmaşaların giderilmesi adına AK Parti araştırma bulgularında şu eğitim politikalarını önermektedir:

- Okul öncesi eğitime verilen önemin arttırılması.

- Temel eğitimde uygulanan müfredatın tekrardan gözden geçirilmesi ve güncellenmesi.

- Milli Eğitim Bakanlığı'nın yönetici değil denetleyici konumda olması.

- Üniversite giriş sınavlarının gözden geçirilmesi ve bu sınavlarda firsat eşitliğinin sağlanması.

- Temel eğitimin ücretsiz olması ve bu eğitim basamağında kalitenin yükseltilmesi, teknoloji kullanımının arttırılması ve öğretmenlerin yeni sisteme uyumunun sağlanması.

- Eğitim sistemleri gelişmiş ülkelerin tecrübelerinden istifade edilmesi.

- Seçmeli ders havuzlarının oluşturulması ve öğrencilerin ilgi ve kabiliyetlerine uygun dersleri seçmesinin özendirilmesi.

- Özel okulların çoğaltılmasının sağlanması ve başarılı öğrencilerin özel okullarda okumaları adına devlet desteğinin sağlanması.

- Mesleki ve teknik okullara gerekli önemin gösterilmesi ve ara eleman ihtiyaçlarının karşılanması adına istihdamlarının gerçekleştirilmesi.

- Tüm öğrencilerin ilgi ve yetenekleri doğrultusunda eğitim almasının sağlanması.

- Üniversite öğrencilerinin masraflarının karşılanması ve yaşam standartlarının yükseltilmesi.

- Meslek yüksek okullarının programlarının güncellenmesi ve ülkedeki ara eleman ihtiyaçlarını karşılayacak nitelikte mezunlar vermelerinin sağlanması.

- Yükseköğretim ile üretim sektörünün ortak projelere imza atmalarının teşvik edilmesi.

- Üniversitelerdeki ar-ge çalışmalarına devlet desteğinin arttırılması ve fon arayışlarının çözümlenmesi.

- Yükseköğretim sisteminde köklü bir reform gerçekleştirilmesi.

- Eğitim kurumlarının mimari yapılarının yenilenmesi ve altyapılarının güncellenmesi.

- Okullardaki rehberlik hizmetlerinin arttırılması ve okul aile birliklerinin desteklenmesi.

- Yabancı dil eğitimlerinin arttırılması ve dil eğitimlerinin teşvik edilmesi.

- Yurtdışında ikamet eden yurttaşların eğitimlerinin gerçekleştirilmesi.

- Din eğitimlerinin niteliğinin arttırılması ve veli gönüllüğü esaslı seçmeli din derslerinin sunulması.

- Uzaktan eğitim ya da online eğitim olarak adlandırılan eğitim uygulamalarının arttırılması.

- Vakıf üniversitelerinin açılmasının desteklenmesi.

- Özel gereksinimli bireylere yönelik çalışmaların desteklenmesi.

Araştırmada elde edilen bulgularda CHP'nin parti programındaki eğitim politikaları incelendiğinde, Eğitimin toplumların aydınlığa ulaşmasında bir yol gösterici olduğuna, eğitim sisteminde insanı merkeze alan çağdaş bir eğitim reformuna ihtiyaç duyulduğuna değinilmiştir. CHP parti programında Türkiye'de

98 | $\mathrm{P}$ a g e

WWW.iiste.org 
nitelikli ve çağdaş eğitim gerçekleştirilebilmesi adına şu politika önerilerini sunmaktadır:

- Laik ve demokratik eğitim ortamlarının oluşturulması.

- Öğrencilere, uzman rehber öğretmen desteklerinin sağlanması.

- Her ortaöğretim öğrencisinin en az bir yabancı dil öğrenmesinin sağlanması.

- Doğu bölgelerinde nitelikli eğitimin gerçekleştirilmesi.

- Ancak zorunlu hallerde taşımalı eğitimin uygulanması, aksi hallerde yerel eğitime devamın sağlanması.

- Yetişkinlerin yaşam boyu öğrenme imkânlarının arttırılması.

- Okuma-yazma seferberliklerinin başlatılması.

- Din kültürü ve ahlak bilgisi eğitimlerinin düzenlemesi.

- Azınlıklara din adamı yetiştirme imkânlarının tanınması.

- Okul öncesi eğitimin yaygınlaștırılmasının sağlanması.

- Çalışan annelerin çocuklarının eğitimde öncelikli olarak ele alınması.

- Eğitim sistemine katılım adına burslar, yardımlar ve fonların oluşturulması.

- Yükseköğretim sisteminin yeniden yapılandırılması, YÖK’ün kaldırılarak Üniversiteler Arası Kurulun etkisinin arttırılması.

- Lisansüstü eğitimlerin desteklenmesi.

- Öğretmenlik mesleğinin saygınlığının tekrardan kazandırılması ve öğretmenliğin statüsünün arttırılması.

- Atama ve istihdam süreçlerinin düzenlenmesi ve kadrolu öğretmenlik sisteminin uygulanması.

Araştırma neticesinde elde edilen bulgularda MHP'nin parti programındaki eğitim politikaları incelendiğinde, Milliyetçi Hareket Partisi’nin tüm bireylerin eğitim öğretim hakkına sahip olduğuna, bu hakkın engellenemeyeceğine ve eğitim-öğretimin devletin kontrolünde yapılması gerektiğine inandığ görülmektedir. MHP özellikle Türkiye'de eğitim dilinin Türkçe olması gerektiğine vurgu yapmakta ve Türkçe'den başka hiçbir dilin Türk vatandaşlarına ana dil olarak okutulup öğretilemeyeceğine değinmektedir. Araştırma bulgularında MHP Türk eğitim sistemi adına şu eğitim politikalarını önermektedir:

- Erdemli ve demokratik nesillerin yetiştirilmesi adına eğitim-öğretimde firsat eşitliğinin sağlanıp, bireylerin ilgi ve yetenekleri doğrultularında eğitilmeleri.

- Türk eğitim sistemi içerisinde eğitim dilinin Türkçe olması.

- Modern eğitim sistemlerinin oluşturulması adına okulların yenilenmesi, müfredatların güncellenmesi ve nitelikli bireylerin yetiştirilmesi.

- Zorunlu eğitim süresinin arttırılması, okul öncesi eğitimin zorunlu olması ve bu standartları sağlama adına altyapı ve istihdamın arttırılması.

- Mesleki teknik eğitimin özendirilmesi, yükseköğretim ve iş yaşamı ile bağlarının kuvvetlendirilmesi.

- Yükseköğretim sisteminin güncellenmesi ve dünya ile rekabet edebilecek seviyelere getirilmesi.

- Yaşam boyu öğrenme faaliyetlerinin arttırılması.

- Nitelikli eğitimcilerin yetiştirilmesi.

- Gazi ve şehit çocuklarına eğitim desteklerinin verilmesi.

- Yurtdışında okuyan vatandaşlara eğitim imkânlarının sağlanması.

Araştırmanın bulgularında İYI Parti programındaki eğitim politikaları incelendiğinde, Türkiye'nin en önemli sorunlarından birisinin eğitim problemleri olduğuna, bu problemlerin de "Eğitim Seferberliği" ile üstesinden gelineceğine, Türkiye'nin 10 yıl içerisinde eğitimde örnek bir ülke haline getirilebileceğine değinilmiştir. Çocukların iyi eğitim almaları adına altyapısı sağlam iyi okulların açılacağına, milli bayramların tekrardan kutlanacağına, nitelikli öğretmenlerin yetiştirileceği "Öğretmen Akademileri" kurulacağına dikkat çekilmiştir. Aynı zamanda "iyi insan" teması ile nitelikli mezunlar ve bireyler yetiştirileceğine değinen İYİ Parti programında Türk eğitim politikaları ile ilgili şu önerilerde bulunulmaktadir:

- Öğretmenliğin cazip ve saygın bir meslek haline getirilmesi.

- Eğitim sisteminde kadın yöneticilerin sayısının arttırılması.

- Türkçe'nin sadeliğinin sağlanması ve kullanım alanlarında saygınlığının korunması.

- Eğitim Planlama ve Koordinasyon (EPKK) kurulunun oluşturulması ve tüm paydaşların katılımı ile uzun vadeli eğitim politikalarının oluşturulması.

- Tüm eğitim basamaklarının esnek ve dinamik bir yapıya sokulması.

- Eğitimin tüm basamaklarında öğrencilerin en az bir spor ya da sanat dalı ile ilgilenmesinin sağlanması.

99|P a g e

www.iiste.org 
- Eğitim sisteminin eğitimcilere ait olması.

- Kamudan eğitime ayrınla payın niteliğinin arttırılması.

- Milli eğitimdeki il ve ilçe eğitim müdürlüklerinin rehber kurumlar olmasının sağlanması.

- Eğitimde insanın merkeze alınmasının sağlanması.

- Kadınların eğitimine önem verilmesi ve yaygın eğitim programlarında yerel yönetimlerin ve Halk eğitim merkezlerinin aktif kullanılması.

- Okul yönetimlerinin başöğretmenlik ve müdürlük olarak ayrılması.

- Öğrencilerin en az bir yabancı dil öğrenmesinin sağlanması.

- Hayata uyum sağlama adına derslerin müfredata eklenmesi ve müfredatın güncellenmesi.

- Uluslararası sınav sonuçlarının önemsenmesi ve bu sonuçlar ile eğitim sistemimizin değerlendirilmesi.

- Yurt dışındaki vatandaşların eğitimlerinin takip edilmesi ve eğitim firsatlarının sunulması.

Araştırmanın bulgularında Saadet Partisi’nin parti programındaki eğitim politikaları incelendiğinde, her bireyin eğitim hakkının bulunduğuna, eğitimin devlet okullarında ücretsiz olması gerektiğine, ilköğretim, ortaöğretimin zorunlu olması, mesleki ve teknik eğitimden tüm bireylerin faydalanması gerektiğine ve yükseköğretimin liyakat ile tüm bireylere açık olmasına değinilmiştir. Saadet Partisi parti programında Türk eğitim sistemi ile ilgili şu politikalar önerilmektedir:

- Değerler eğitimi odaklı eğitim sistemlerinin oluşturulması.

- Nitelikli insan gücünün yetiştirilmesinin sağlanması.

- Eğitimde firsat eşitliğinin sağlanması.

- Kalıcı ve uzun süreli eğitim politikalarının olușturulması.

- İlmi gereksinimler temelli eğitim reformunun gerçekleştirilmesi.

- Divan Edebiyatı ve Bilimler Tarihi derslerinin müfredata dâhil edilmesi.

- 4+4+3 zorunlu eğitim ve öğretim modelinin uygulanması.

- Yükseköğretim geçişlerinde firsat eşitliğinin sağlanması.

- Mesleki teknik eğitimin geliştirilmesi, meslek edindirme kursları ve çıraklık eğitimlerinin arttırılması.

- Din eğitimlerinin 18 yaşına kadar veli izni ile 18 yaşından sonra kendi isteklerine göre verilmesi.

- Üniversitelerin kaynak problemlerinin çözülerek, akademik çalışmalara yoğunlaşmalarının sağlanması.

- Yükseköğretim kuruluşlarının serbest bırakılması.

- YÖK'ün kaldırılması ve yerine devlet birimlerinde bir üst kurulun oluşturulması.

- Özel gereksinimli bireylerin eğitilmesi gerekli tedbirlerin alınması.

Araştırmanın bulgularında HDP'nin parti programındaki eğitim politikaları incelendiğinde, her vatandaşın kendi kültürü temelli eğitim alması gerektiğine, ana dilde eğitim verilmesinin tüm vatandaşların hakkı olduğuna bu neticede eğitim sisteminin tüm basamaklarında anadil kullanılmasının serbest olması gerektiğine değinilmiştir. HDP parti programında Türk eğitim sistemi ile ilgili şu politika önerileri mevcuttur:

- Türkiye'de tüm dillerin üniversitelerde konuşulabilmesi.

- Meslek liselerinin niteliklerinin arttırılması.

- Okul öncesi eğitimin zorunlu olması.

- Eğitim sistemindeki basamaklar arasındaki geçişlerin sınavsın planlanması.

- Müfredatın yenilenmesi gereksinimi.

- Özel gereksinimli vatandaşların eğitilmesi adına engellerin kaldırılması.

- Eğitimde merkezi yönetim yerine yerel yönetimlerin desteklenmesi.

- Diyanetin kaldırılması ve zorunlu din derslerinin zorunluluktan çıkarılması.

- Alevi vatandaşların eşit yurttaşlık, eğitim ve ibadet haklarının tanınması.

- Rekabetçi ve eşit olmayan eğitim sistemlerinin reddedilmesi.

- YÖK’ün kaldırılması ve üniversitelerin özgürleştirilmesi.

- Yükseköğretimin tamamen parasız olması ve yükseköğretime geçiş sınavlarının kaldırılması.

- Üniversite öğrencilerine yönelik burs ve yurt imkânlarının sunulması.

- Eğitimin; milliyetçi, ayrıştırıcı, cinsiyetçi öğelerden ayıklanması.

- Demokrasi ve insan hakları derslerinin ilk ve ortaöğretimde önem kazanması.

Mevcut araştırma bulgularında 2002 yılından beri eğitim politikalarını uygulayabilen tek parti olan AK Parti'nin gerçekleştirdiği faaliyetlere yer verilmiştir. Bu çalışmalar neticesinde AK Parti'nin programında ve seçim bildirgelerinde vaat ettiği uygulamaları eğitim sistemine yansıtma gayreti içerisinde olduğu

$\mathbf{1 0 0} \mid \mathrm{P}$ a g e

WWW.iiste.org 
görülmektedir. $\mathrm{Bu}$ sebeple $\mathrm{AK}$ Parti Türk eğitim sistemini tüm bireylerin erişebileceği bir hale dönüştürmüştür. Ders kitaplarını ücretsiz dağıtarak velileri ciddi bir ekonomik yükten kurtarmıştır. Ekonomik durumu olmayan ailelere çocuklarını düzenli olarak okula göndermeli şartı ile maddi destekler sağlanmıştır. $\mathrm{Bu}$ maddi destekler, aile içerisindeki saygınlığının artması adına annelerin hesaplarına yatırılmıştır. Okuma-yazma seferberlikleri ile beraber yaşam boyu öğrenme faaliyetleri arttırılmıştır. Öğrencilere verilen burs miktarları sembolik rakamlar olmaktan çıkarılmıştır. Özel okulların erişilmezlik algısı toplumda değiştirilmiş ve özel okul teşvikleri verilmiştir. Eğitimde gerçekleştiren reform düzeyindeki düzenlemeler ile 28 Şubat'ın izleri silinmiş ve eğitimde bir kara leke olarak duran başörtüsü yasağ 1 uygulamasına son verilmiştir. Eğitimde tek tip uygulamalara son verilerek farklı inanç ve görüşlere sayg1 duyulmaya başlanmıştır. 4+4+4 eğitim sistemine geçilerek müfredattaki anti-demokratik içerilerden arınılmıştır. Toplum bilincinin kazandırılması adına "Adalet ve Hukuk" ve öğrencilerin İslam dinini doğru öğrenmesi adına "Siyer" ve "Kuran-1 Kerim” dersleri seçmeli ders olarak müfredata eklenmiştir. FATİH projesi ile teknolojiye erişilebilirlik arttırılmış ve eğitimdeki teknolojik alt yapı eksiklikleri giderilmiştir. Okul öncesi eğitim hizmetleri ücretsiz olarak arttırılarak, zorunlu eğitim öncesinde çocukların en az 1 sene okul öncesi eğitim almaları hedeflenmiştir. Gençler için sosyal bilimlerin önemi anlaşılmış ve Türkiye'de ilk defa sosyal bilimler liseleri açılmıştır. Yine sanat ve spor alanlarında nitelikli bireylerin yetişmesi adına spor ve sanat liseleri açılmıştır. Meslek liselerinin önündeki ideolojik engeller ortadan kaldırılarak, meslek liselerinden mezun olarak yükseköğretime geçiş yapmak isteyen öğrencilerin katsayı problemleri giderilmiştir. 81 ilde üniversiteler açılmış ve üniversitelerin sayıları 186'ya çıkarılmıştır. "Milli Savunma Üniversitesi" kurulmuş ve savunma faaliyetlerinin daha bilinçli yapılabilmesi adına nitelikli bireylerin eğitilmesi amaçlanmıştır. Okullaşma oranları \%13 seviyesinden \%43 seviyesine yükseltilmiş, 2002 y1lında 1.9 milyon olan öğrenci sayısı 2019 yılında 7.2 milyona çıkarılmıştır. Üniversite öğrencilerinin maddi imkânsızlıklarını gidermek adına 3 milyar TL olan bütçe 11 kat arttırılarak 41 milyara yükseltilmiştir. Özel gereksinimli bireylerin eğitim ve rehabilitasyonları adına 2006-2018 yılları arasında 15 milyar TL kaynak ayrılmıştır. Öğretmenlerin istihdamı noktasında cumhuriyet tarihinde en kapsamlı atamalar AK Parti döneminde gerçekleştirilmiştir. İstihdam süreçleri ile beraber öğretmenlerin yaşam ve mesleki standartlarının iyileştirilmesi yönelik faaliyetler gerçekleştirilmiştir. 2018 yılı itibarı ile toplam öğrenci sayıs1 900.000'leri bulmuş, 3.200 civarında da engelli öğretmen istihdamı gerçekleştirilmiştir. Aynı zamanda 950 milli sporcunun da öğretmen olarak atanması sağlanmış ve ülke genelinde öğretmen normlarının doluluk oranı $\% 90$ seviyelerine çıkartılmıştır.

\section{Kaynakça}

Adalet ve Kalkınma Partisi. (2018). Eğitim ve kültür. Web site: http://www.akparti.org.tr/site/akparti/ 2023-siyasi-vizyon\#bolum_adresinden 29 Kasım 2018 tarihinde edinilmiştir.

Adalet ve Kalkınma Partisi. (2018). Eğitim. Web site: http://www.akparti.org.tr/site/akparti/partiprogrami\#bolum_adresinden 29 Kasım 2018 tarihinde edinilmiştir.

Adalet ve Kalkınma Partisi. (2018). Seçim Beyannamesi. Web site: http://www.akparti.org.tr/site/ dosya/59647. adresinden 05 Aralık 2018 tarihinde edinilmiştir.

Akça, Y., Esen, Ş. \& Özer, G. (2018). Siyasi parti beyannamelerinde eğitim politikalarının değerlendirilmesi. Full Texts Book of the 3rd International Eurasian Conference on Sport Education and Society. (15-18 November 2018) Mardin, TURKEY.

Aksoy, H.H., Aras, H.Ö., Çankaya, D. \& Karakul, A.K. (2011). Eğitimde nitelik: Eğitim ekonomisi kuramlarının eğitimin niteliğine ilişkin kurgusunun eleştirel analizi. Eğitim Bilim Toplum, 9(33), 6099.

Altınışık, S. \& Songür, N. 2015 Genel Seçimlerinde Barajı Geçen Partilerin Eğitimin Niteliğine İlişkin Politikalarının. Çăgdaş Yönetim Bilimleri Dergisi, 3(1), 1-20. 
International Journal of Scientific and Technological Research

ISSN 2422-8702 (Online), DOI: 10.7176/JSTR/6-06-07

Special Issue of Educational Sciences, Vol.6, No.6, 2020

Atmış, E. \& Günşen, H.B. (2016). Political parties and forestry relations in Turkey's general elections in 2015. Journal of the Faculty of Forestry Istanbul University 66(2), 587-599.

Berber, Ş. (2001). Türkiye'deki siyasi partiler ve eğitim politikaları. Selçuk Üniversitesi Sosyal Bilimler MYO Dergisi, 4( 2), 1-34.

Berber, Ş. (2004). Türkiye'deki siyasi partiler ve eğitim politikalari. Selçuk Üniversitesi Sosyal Bilimler Meslek Yüksek Okulu Dergisi, 4(2), 1-34.

Bulut, P. \& Güven, S. (2013). Siyasi parti programlarında ilköğretim. Eğitimde Kuram ve Uygulama, $6(2), 281-300$.

Büyükboyacı, Ş. (2015). Süleyman Demirel dönemi (1965-1971) eğitim politikaları ve uygulamalarının Türk basınındaki yankıları. Ulakbilge Sosyal Bilimler Dergisi, 3(6), 19-57.

Cumhuriyet Halk Partisi. (2015). Cumhuriyet Halk Partisi Programı. Web site:https://chp.azureedge. net/1d48b01630ef43d9b2edf45d55842cae.pdf.adresinden 05 Aralık 2018 tarihinde edinilmiştir.

Çepni, S. (2010). Araştırma ve Proje Çalışmalarına Giriş, Trabzon.

Güllüpınar, F. \& Bakış, T. (2015). Türkiye’de iktisadi dönüşümler ve eğitim politikaları.(Edit: Gümüş, A., Türkiye'de eğitim politikaları), Nobel Akademik Yayıncılık, 2015.

Gürsoy, M. \& Balcı Karaboğa, A. (2015). Siyası Partilerin Seçim Bildirgelerinde Eğitim Konusu. Route Educational and Social Science, 2(4), 112-140.

Halkların Demokratik Partisi. (2018). Parti Programı. Web site: https://www.hdp.org.tr/tr/parti/partiprogrami/8. adresinden 29 Aralık 2018 tarihinde edinilmiştir.

İyi Parti. (2018). İyi Parti Programı. Web site: https://iyiparti.org.tr/Assets/pdf/iyipartiprogrami.pdf. adresinden 28 Kasım 2018 tarihinde edinilmiştir.

Kapani, M. (2006). Politika bilimine giriş, bilgi yayınevi. 18. Basım, Ankara.

Korkmaz, F. (2018). Siyasi Partilerin 2018 Cumhurbaşkanlığı Seçimi ve Genel Seçimler Bildirgelerinde Eğitime Yönelik Görüşlerinin İncelenmesi. Çă̆daş Yönetim Bilimleri Dergisi, 5(3), 297-315.

Milliyetçi Hareket Partisi. (2009). Parti Programı “Geleceğe Doğru”. Web site: https://www.mhp.org. tr/usrimg/mhp2007/kitaplar/mhppartiprogrami2009opt.pdf. adresinden 28 Kasim 2018 tarihinde edinilmiştir.

Özdem, G. (2015). Türkiye'de eğitim politikaları alanında yapılan lisansüstü tezlerin incelenmesi (19892014). Gaziantep University Journal of Social Sciences, 14(3).

Saadet Partisi. (2014). Saadet Partisi Programı. Web site: http://www.saadet.org.tr/program.pdf. adresinden 05 Aralık 2018 tarihinde edinilmiştir.

Su, Ş. (2017). Adalet ve Kalkınma Partisi Dönemi 59. ve 60. Hükümetlerinde Eğitim Politikaları. Eğitim Kuram ve Uygulama Araştırmaları Dergisi, 3(1), 12-22.

Şahin, M. O. (2011). Türkiye'de 2007 milletvekili genel seçimleri ışı̆̆ında siyasal partiler ve seçmenlerinin Avrupa Birliği'ne yönelik tutumları. Bilimsel araştırma projesi, İstanbul Üniversitesi Sosyal Bilimler Enstitüsü, İstanbul. 
International Journal of Scientific and Technological Research

ISSN 2422-8702 (Online), DOI: 10.7176/JSTR/6-06-07

Special Issue of Educational Sciences, Vol.6, No.6, 2020

Şimşek, A., Özdamar, N., Uysal, Ö., Kobak, K., Berk, C., Kılıçer, T., \& Çiğdem, H. (2009). İkibinli yıllarda Türkiye'deki eğitim teknolojisi araştırmalarında gözlenen eğilimler. Kuram ve Uygulamada Ĕ̈itim Bilimleri Dergisi, 9(2), 115-120.

Şişman, M. (2007). Örgütler ve kültürler: örgüt kültürü. Pegem A Yayıncılık.

Türk Eğitim Derneği. (2018). Siyasi partilerin 2018 seçim bildirgeleri: eğitim alanındaki politika ve vaatlerin karşılaştırılması. Web site: https://tedmem.org/mem-notlari/gorus/siyasi-partilerin-2018secim- bildirgeleri-egitim-alanindaki-politika-ve-vaatlerin-karsilastirilmasi adresinden 02.02.2020 tarihinde edinilmiştir.

Usta, M. E. (2015). Siyasi parti programlarına göre eğitim politikaları. TYB Akademik Dil Edebiyat ve Sosyal Bilimler Dergisi, 55-73. 